\title{
Evolution of the Major Moss Lineages: Phylogenetic Analyses Based on Multiple Gene Sequences and Morphology
}

\author{
Angela E. Newton and Cymon J. Cox ${ }^{1}$ \\ Department of Botany, Natural History Museum, London SW7 5BD, U.K.
}

JEFFREY G. DUCKETT

School of Biological Sciences, Queen Mary and Westfield College, London E1 4NS, U.K.

JOHN A. WHEELER

University and Jepson Herbarium, University of California, Berkeley, CA 94720, U.S.A.

BERNARD GOFFINET

Department of Ecology and Evolutionary Biology, University of Connecticut, Storrs CT 06268-3043, U.S.A.

TERry A. J. HedDERSON

Department of Botany, University of Cape Town, Private Bag, Rondebosch 7701, South Africa

BRENT D. Mishler

University and Jepson Herbarium, University of California, Berkeley, CA 94720, U.S.A.

Abstract. Evolutionary relationships of mosses are still poorly understood, with family, order, and subclass circumscription and relationships remaining especially obscure. Over the past decade, a considerable body of data has accumulated, including information on morphological, developmental, anatomical, and ultrastructural characteristics, as well as nucleotide sequences for a number of nuclear and plastid genes. We have combined data from these different sources to provide an overview of the relationships of the major lineages of mosses. We analyzed a data set that includes 33 moss species and ten outgroup taxa drawn from the liverworts, hornworts, and vascular plants. Molecular data consisted of nucleotide sequences from four DNA regions, ( $\mathrm{rbcL}, \operatorname{trn} L-\operatorname{trn} F$, rps 4 and 18S). Morphological data included 41 characters of which many were derived from published anatomical and ultra-structural studies. Combining morphological and molecular data in the analyses showed that mosses, including Sphagnum, Takakia, Andreaea and Andreaeobryum, form a monophyletic group, provided improved resolution of higher level relationships, and further insight into evolutionary patterns in morphology.

Among extant land plants, mosses are the second most speciose group after the angiosperms, and, together with liverworts, contribute a significant fraction of the species diversity in many environments, including those (desert, high montane, and high latitude) where vascular plants are sparse or absent. Their physical structure and physiological attributes (for example, desiccation resistance/drought tolerance, nutrient-capturing abilities) allow them to play major roles in many of the world's ecosystems, affecting water and mineral fluxes, controlling surface run-off and erosion, and providing food and habitat for a wide range of organisms including other plants, fungi, bacteria, invertebrates, birds, and mammals. They are a remnant of one of the earliest branching events in the radiation of the plants on land, and systematic studies of mosses should consequently provide substantial information relevant to the understanding of land plant origins, evolution, and diversity. Although in recent years there have been an increasing number of phylogenetic studies involving mosses, using either morphological or molecular data, most have been focused at different taxonomic levels, either higher (green plants or land plants) or lower (family or genus). In this analysis, we aim to use molecular data from four different gene sequences, in combination with morphological data from a range of character systems in both the gametophyte and sporophyte, to address the relationships of the major lineages of mosses. The relationship of mosses to the other bryophyte lineages and the land plants is not considered here, nor are the details of relationships within the major moss lineages, which will be addressed later in this symposium volume.

Mosses and other "bryophytes" (hepatics and hornworts) have been shown by numerous studies (e.g., Duff \& Nickrent 1998; Hedderson et al. 1998; Kenrick \& Crane 1997; Mishler \& Churchill 1984) to be descended from some of the earliest terrestrial 
TABLE 1. List of taxa sampled for molecular sequences, with GenBank accession numbers. Voucher information can be obtained from the GenBank accession file. Major lineages are indicated although not all taxonomic levels are included. Taxonomy follows Kenrick and Crane (1997) for out-group classification and Vitt (1984) and Vitt et al. (1998) for mosses.

\begin{tabular}{|c|c|c|c|c|}
\hline \multirow[b]{2}{*}{ Taxon } & \multicolumn{4}{|c|}{ GenBank accession numbers } \\
\hline & $18 \mathrm{~S}$ & rps 4 & trnL-F & $r b c \mathrm{~L}$ \\
\hline \multicolumn{5}{|l|}{ TRACHEOPHYTA } \\
\hline \multicolumn{5}{|l|}{ Liliopsida } \\
\hline Zea mays $\mathrm{L}$. & U42796 & X86563 & X86563 & X86563 \\
\hline \multicolumn{5}{|l|}{ Equisetopsida } \\
\hline Equisetum hyemale $\mathrm{L}$. & U18500 & - & - & - \\
\hline Equisetum bogotense $\mathrm{HBK}$ & - & AF231898 & - & - \\
\hline Equisetum arvense $\mathrm{L}$. & - & - & - & L11053 \\
\hline \multicolumn{5}{|l|}{ Filicopsida } \\
\hline Lygodium japonicum (Thundb.) Swartz & AB001538 & - & - & U05632 \\
\hline Asplenium australasicum (J. Sm.) Hook. & D85303 & - & - & AB01324 \\
\hline \multicolumn{5}{|l|}{ ANTHOCEROPHYTA } \\
\hline Notothylas breutelii Gottsche & AF126292 & - & - & AF231888 \\
\hline Anthoceros agrestis Paton & X80984 & - & - & \\
\hline Anthoceros punctatus L. & - & - & - & U87063 \\
\hline \multicolumn{5}{|l|}{ MARCHANTIOPHYTA } \\
\hline Lophocolea heterophylla (Schrad.) Dumort. & X89872 & AF231889 & AF231899 & U87076 \\
\hline Haplomitrium hookeri (Sm.) Nees & U18504 & AF231890 & AF231900 & U87072 \\
\hline Sphaerocarpus texanus Austin & U18522 & AF231891 & AF231901 & U87090 \\
\hline Marchantia polymorpha $\mathrm{L}$. & $\mathrm{X} 75521$ & X04465 & X04465 & U87079 \\
\hline \multicolumn{5}{|l|}{ BRYOPHYTA } \\
\hline \multicolumn{5}{|l|}{ Sphagnales } \\
\hline Sphagnum palustre $\mathrm{L}$. & AF126290 & AF231892 & AF231902 & AF231887 \\
\hline Sphagnum cuspidatum Hoffm. & X80213 & AF231893 & AF231903 & AF231886 \\
\hline \multicolumn{5}{|l|}{ Takakiales } \\
\hline Takakia lepidozioides Hatt. \& Inoue & U18526 & AF231894 & AF231904 & AF231058 \\
\hline \multicolumn{5}{|l|}{ Andreaeales } \\
\hline Andreaea rothii Web. \& Mohr & X99750 & - & AF231905 & AF231060 \\
\hline \multicolumn{5}{|l|}{ Andreaeobryales } \\
\hline Andreaeobryum macrosporum Steere \& B. Murr. & $\mathrm{AJ} 275005$ & - & AF231906 & AF231059 \\
\hline \multicolumn{5}{|l|}{ incertae sedis } \\
\hline Oedipodium griffithianum (Dicks.) Schwaegr. & AF228668 & - & AF246290 & AF246289 \\
\hline \multicolumn{5}{|l|}{ Polytrichales } \\
\hline Polytrichum commune Hedw. & $\mathrm{U} 18518$ & AF208428 & AF231907 & LJ87087 \\
\hline Dawsonia papuana Schlieph. \& Geheeb & AF228669 & AF208419 & AF246704 & AF208410 \\
\hline \multicolumn{5}{|l|}{ Tetraphidales } \\
\hline Tetraphis pellucida Hedw. & U18527 & AF231896 & AF231908 & U87091 \\
\hline \multicolumn{5}{|l|}{ Buxbaumiales } \\
\hline Buxbaumia aphylla Hedw. & - & AF231897 & AF231909 & AF231062 \\
\hline \multicolumn{5}{|l|}{ Diphysciales } \\
\hline Diphyscium foliosum (Hedw.) Mohr & AJ275008 & AF223034 & AF229891 & AF232692 \\
\hline \multicolumn{5}{|l|}{ Funariales } \\
\hline Funaria hygrometrica Hedw. & X74114 & AF023776 & AF023716 & AF005513 \\
\hline \multicolumn{5}{|l|}{ Timmiales } \\
\hline Timmia sibirica Lind. \& Arnell & AF023678 & AF023775 & AF023715 & AJ275166 \\
\hline \multicolumn{5}{|l|}{ Encalyptales } \\
\hline Bryobrittonia longipes (Williams) Horton & AF023679 & AF023778 & AF023718 & AJ275168 \\
\hline Encalypta rhaptocarpa Schwaegr. & AF023680 & AF023777 & AF023717 & AJ 275168 \\
\hline
\end{tabular}


TABle 1. Continued.

\begin{tabular}{|c|c|c|c|c|}
\hline \multicolumn{5}{|l|}{ Dicranidae } \\
\hline Dicranum scoparium Hedw. & X89874 & AF234158 & AF234159 & AF231067 \\
\hline Tortula ruralis (Hedw.) G.M.S. & AF023682 & AF023831 & AF023722 & AJ275169 \\
\hline Ptychomitrium gardneri Lesq. & AF023689 & AF023779 & AF023719 & AF005549 \\
\hline Scouleria aquatica Hook. & AF023684 & AF023780 & AF023723 & AF226822 \\
\hline Drummondia prorepens (Hedw.) E. Britt. & - & - & - & AF005542 \\
\hline Drummondia obtusifolia Mitt. & - & AF223038 & AF229895 & - \\
\hline \multicolumn{5}{|l|}{ Splachnales } \\
\hline Splachnum ampullaceum Hedw. & $\mathrm{AJ} 275007$ & $\mathrm{AJ} 251308$ & AF215899 & AF231071 \\
\hline \multicolumn{5}{|l|}{ Orthotrichales } \\
\hline Orthotrichum lyellii Hook. \& Tayl. & AF025291 & AF023814 & AF023727 & AF005536 \\
\hline \multicolumn{5}{|l|}{ Hedwigiales } \\
\hline Hedwigia ciliata (Hedw.) P. Beauv. & $\mathrm{AJ} 275010$ & AF005517 & - & AJ251309 \\
\hline \multicolumn{5}{|l|}{ Bryales } \\
\hline Leptobryum pyriforme (Hedw.) Wils. & X80980 & AF023802 & AF023736 & AF231072 \\
\hline Rhodobryum giganteum (Schwaegr.) Par. & AF023699 & AF023789 & AF023737 & AJ 275176 \\
\hline Mnium hornum Hedw. & X80985 & AF023796 & $\mathrm{AF} 023767$ & - \\
\hline Mnium thomsonii Schimp. & - & - & - & AF005518 \\
\hline Philonotis fontana (Hedw.) Brid. & AF023694 & AF023801 & AF023758 & - \\
\hline Philonotis revoluta Bosche and Sande Lac & - & - & - & AF231091 \\
\hline Hypnodendron dendroides (Brid.) Touw & AJ275012 & AF023822 & AF023746 & - \\
\hline Hypnodendron menziesii (Hook.) Paris & - & - & - & AF231093 \\
\hline Bescherellia brevifolia Hampe & AJ251098 & $\mathrm{AJ} 251313$ & AF215903 & AJ275184 \\
\hline Racopilum tomentosum (Hedw.) Brid. & AF229921 & $\mathrm{AJ} 251314$ & AF215904 & - \\
\hline Racopilum convolutaceum (C. Müll.) Reichdt. & - & - & - & AF231094 \\
\hline \multicolumn{5}{|l|}{ Hookeriales } \\
\hline Hookeria lucens (Hedw.) Sm. & $\mathrm{AJ} 275013$ & $\mathrm{AJ} 251316$ & AF215906 & - \\
\hline Hookeria acutifolia Hook. \& Grev. & - & - & - & AF158170 \\
\hline \multicolumn{5}{|l|}{ Leucodontales } \\
\hline Fontinalis antipyretica Hedw. & AF023714 & AF023817 & AF023771 & AJ275183 \\
\hline \multicolumn{5}{|l|}{ Hypnales } \\
\hline Hypnum lindbergi Mitt. & AF229922 & AF143035 & AF161128 & AF232696 \\
\hline
\end{tabular}

embryophytes. Extant bryophytes possess numerous features that reflect their shared history with embryophytes. These features include multi-cellular sporophytes retained on the gametophyte, cuticle, archegonia, and antheridia. However, they also retain plesiomorphic characters such as dependence on free surface water for fertilization by flagellate spermatozoids, simple vascular tissue (lacking true lignin), and unbranched sporophytes. As such, these plants represent a model of the early land plants. By providing insights for evolutionary patterns in the morphology and diversity of early land plants, studies of bryophytes enhance our understanding of the origins and maintenance of land plant diversity. However, despite this, bryophytes are often disregarded, both in discussions of biodiversity and systematics (e.g., Judd et al. 1999). Hence, the evolutionary relationships of the "bryophytes" at many levels are still poorly understood. Within mosses, the subclass, order, and family circumscriptions and relationships remain particularly obscure.

Studies involving the relationships of the major lineages of mosses will a) contribute to the understanding of the processes of evolution, particularly the colonization of the terrestrial environment; $b$ ) generate phylogenetic hypotheses to facilitate the study of morphological and molecular evolution across all embryophytes; c) provide backbone classifications, which in turn facilitate systematic studies with a narrower focus by identifying outgroups, sister groups, and monophyletic groups for further study; and d) provide robust classifications that are essential for other users-for example, ecologists, conservationists, and physiologists to facilitate plant identification and to provide the basis for meaningful comparisons.

This work has been facilitated by taking a collaborative approach, with a series of nested analyses focusing on lineages at different levels of inclusiveness, not only among the bryophytes, but among all green plants from the green algae to the angiosperms, as part of the Green Plant Phylogeny Research Co-ordination Group (http://ucjeps.berkeley.edu/bryolab/ greenplantpage.html). Across such a wide range of taxa, methodological issues may cause serious prob- 


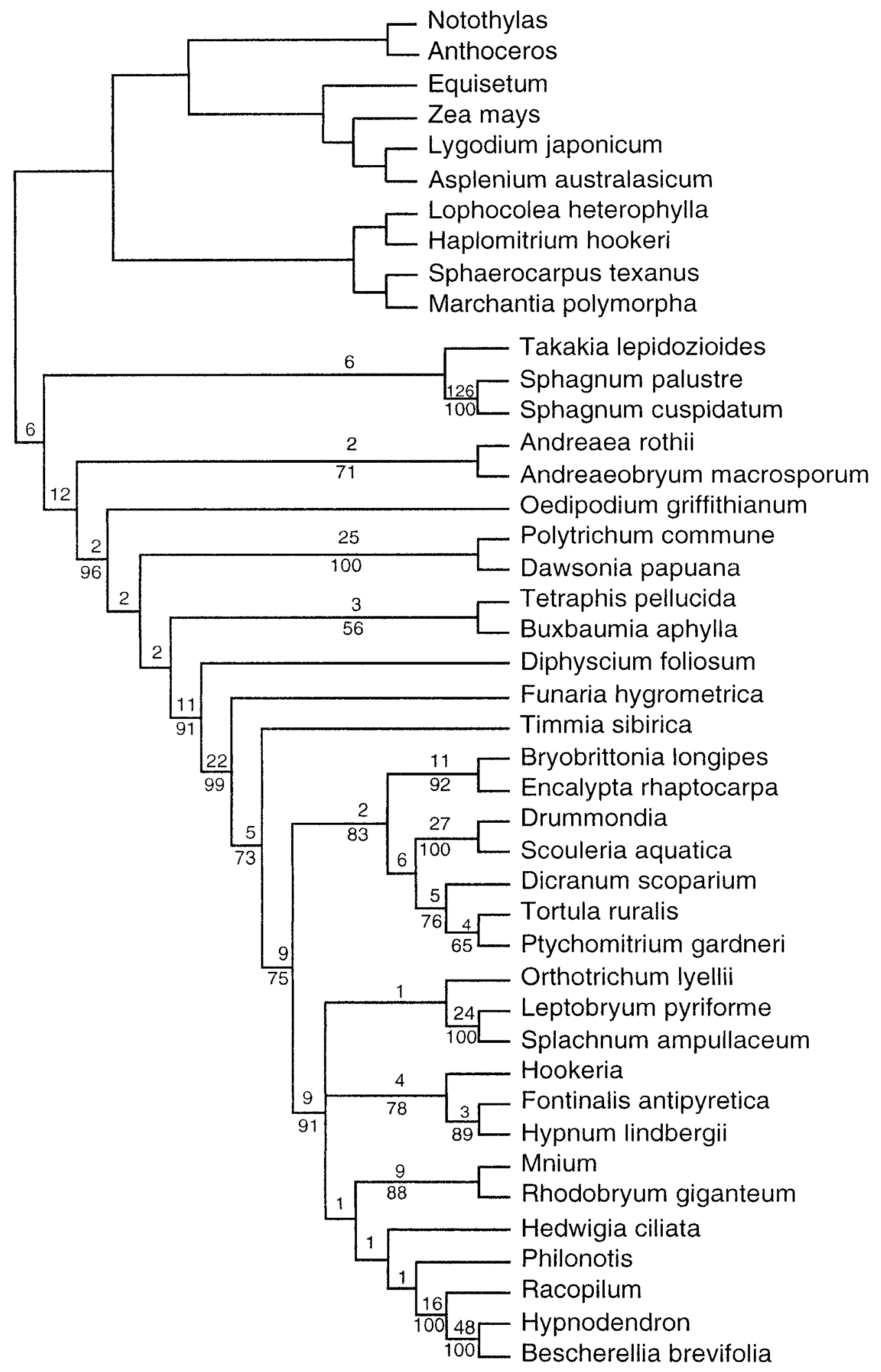


lems including those related to the analysis of large data sets, adequacy of taxon sampling, comparability of characters across distantly related lineages, homoplasy, and site saturation. Although it is not currently possible to include dense representation of all green plants simultaneously, analysis of large data sets is increasingly feasible (Chase \& Cox 1998). Another approach, compartmentalization (Mishler 1994), examines phylogenetic topologies locally (within related groups) to reduce problems with taxon sampling and the comparison of distantly related taxa, and then links these local analyses to global ones. A related approach involves the use of exemplars, chosen with reference to existing knowledge of phylogenetic structure to organize sampling. Ideally, sampling in any given taxon should span the root node and reflect different rates of diversification (Sanderson 1996), if this information is available. With both these strategies different workers and laboratory groups can study different subgroups, then combine them in global analyses.

In this study, we are concerned primarily with the monophyly of mosses and with the relationships of the major lineages of mosses. We address three questions 1) Are Sphagnum, Andreaea, Andreaeobryum, and Takakia part of the moss lineage, or do one or more of these taxa represent other lineages more closely related to other land plants? 2) within the mosses how are the major groups related? and 3 ) what are the evolutionary patterns in the characters used?

The extant moss taxa are too numerous to include more than a small proportion in a single study so to facilitate phylogenetic analysis, exemplars were selected for the major lineages and critical taxa identified from previous work. Certain groups, for example the Sphagnales, the Polytrichales, and the Tetraphidales (Crum \& Anderson 1981; Vitt 1984; Vitt et al. 1998), with their unique and highly distinctive morphologies, are non-controversial and widely recognized as monophyletic. Other groups contain components whose relationships are not clearly understood as yet, for example, the Andreaeopsida (sensu Vitt et al. 1998) represented by Andreaea, Andreaeobryum, and Takakia. The haplolepidous mosses, now recognized as the Dicranidae (Vitt et al. 1998), are represented by Dicranum, Scouleria, Grimmia, Ptychomitrium, Tortula, and Drummondia. The first five of these are noncontroversial, representing the Dicranales, Grimmiales, and Pottiales. However, Drummondia was only recently excluded from the Orthotrichales and transferred to the haplolepidous mosses on the basis of molecular data (Goffinet et al. 1998). The problematic Encalyptales, sometimes included with the haplolepidous Pottiales (Crum \& Anderson 1981), are represented by Encalypta and Bryobrittonia. Representatives of the distal arthrodontous clades were selected from the principal orders. The group consisting of the Hypnales, Leucodontales, and Hookeriales (sensu Vitt 1984), but excluding the Racopilaceae, has been shown to form a monophyletic group in several recent studies (De Luna et al. 1999; Hedenäs 1994; Newton \& De Luna 1999; Withey 1996), and for convenience are referred to here as the meta-pleurocarps.

Other (and partially overlapping) research groups are working on relationships within the major lineages, and the results of these studies will be presented in this symposium volume. The groups represented are the Sphagnales (Shaw laboratory, Duke); haplolepidous mosses (Mishler laboratory, Berkeley, and La Farge, Edmonton); basal arthrodontous mosses and Orthotrichales (Goffinet \& collaborators, Storrs); distal arthrodontous mosses (Cox \& collaborators, London); pleurocarpous mosses (De Luna, \& collaborators, Xalapa). The work in the current paper represents collaboration between all of these sub-groups, and many others around the world, which provided data, ideas, or both.

\section{MATERIALS AND METHODS}

Choice of exemplars and source of materials.-Ingroup taxa used in this study were selected to represent the major lineages of mosses, as established from the results of previous research, including both monographic and cladistic studies. Taxonomy follows Kenrick and Crane (1997) for out-group taxa, and Vitt et al. (1998) for mosses. Full data for the species included are listed in Table 1, with GenBank accession numbers. The 33 exemplars for the in-group include Sphagnum (2), Andreaea, Andreaeobryum, Takakia, Polytrichales (2), Oedipodium, Tetraphis, Buxbaumia, Diphyscium, Encalyptales (2), with five haplolepidous and 13 diplolepidous taxa drawn from the Funariales, Splachnales, Orthotrichales, Bryales, Hypnales, Leucodontales, Hookeriales, Pottiales, and Dicranales. Ten outgroup taxa, representing four vascular plants, two hornworts, and four liverworts, are included.

Some of the taxa used are composite, in that the character information is derived from more than one individual or species. For example, different nucleotide sequences might be derived from different specimens and extracted in different laboratories, while the morphological data rep-

FIgURE 1. Strict Consensus of two MPT's (Length 4,651, CI $=0.359$, RI $=0.456$ ) found by parsimony analysis of combined 18S, rps4, trnL-trnF, and $r b c \mathrm{~L}$ sequence data for all taxa. All sites were weighted equally. Bootstrap percentages (1,000 replicates) shown below branches, decay indices above branches. 
resent observations on a number of individuals. In some cases, where sequence or morphological data are not available from the same species, observations are made on individuals from different species. These taxa are shown with generic names only in the figures.

DNA extraction, PCR-amplification and sequencing.Many sequences are taken from other publications or from GenBank (Cox et al. 2000; Goffinet \& Cox 2000; La Farge et al. 2000; Mishler, unpubl. data; Wheeler et al. 2000) and 25 sequences were newly generated for this paper (Table 1). Standard methods were used to determine the DNA sequences, however protocols varied in minor details between the laboratories involved in the data collection. A representative methodology is given below.

Total genomic DNA was extracted using a CTAB extraction procedure (Rogers \& Bendich 1994), cleaned using the Wizard DNA Clean-up Kit (Promega), and eluted into $50 \mu \mathrm{l}$ of sterile water. Double-stranded DNA templates were prepared using the polymerase chain reaction (PCR), employing 30 cycles of one min. at $97^{\circ} \mathrm{C}, 1 \mathrm{~min}$. at the primer annealing temperature $\left(18 \mathrm{~S}-50^{\circ} \mathrm{C} ; r b c \mathrm{~L}-\right.$ $48^{\circ} \mathrm{C}$; $r p s 4$, and $\operatorname{trn} \mathrm{L}-\mathrm{F}-52^{\circ} \mathrm{C}$ ) and three min. at $72^{\circ} \mathrm{C}$, preceded by an initial melting step of one min. at $97^{\circ} \mathrm{C}$, and followed by a final extension step of seven min at $72^{\circ} \mathrm{C}$. PCR was performed in $100 \mu l$ reaction volumes $(1 \times$ thermostable buffer, $2.5 \mathrm{mM} \mathrm{MgCl}_{2}, 200 \mu \mathrm{m}$ dNTPs, $300 \mu \mathrm{m}$ primer, 2.5 units Taq polymerase (Promega, storage buffer A) and $1-0.1 \mu 1$ of template DNA) using the following primer combinations: $18 \mathrm{~S}$ rDNA-NS1 and PCRB; $r b c \mathrm{~L}-$ NM34, and MtmRR; rps4-rps5 and trnas; trnL-F-trnC and $\operatorname{trnF}$ (for amplification and sequence primers see Cox et al. 2000). The resulting double-stranded DNA amplification products were cleaned on a QIAquick PCR Purification (Qiagen) spin column and eluted into $30 \mu \mathrm{l}$ of sterile water. Sequence reactions were prepared using the ABI PRISM BigDye Terminator Cycle Sequencing Ready Reaction Kit (Perkin-Elmer), in accordance with the manufacturers instructions, using the following sequence primers: $18 \mathrm{~S}$ rDNA-NS1, 18H, 18G, 18J, 18ERC, 18KRC; rbcL-NM34, M636, M745, M1390R; rps4-rps5, trnas; trn $\mathrm{L}-\mathrm{F}-\operatorname{trn} \mathrm{C}$, trnF). Sequence products were resolved on an ABI (model 377) automated sequencing machine.

Sequence manipulation and alignment.-Electropherograms were edited and forward and reverse sequences assembled for each DNA region using SeqMan II (LaserGene System Software, DNAStar, Inc.). The consensus sequences of all four regions for each taxon were concatenated into a single sequence using SeqEdit and aligned manually in MegAlign (LaserGene System Software, DNAStar, Inc.). The resulting alignment was exported as a Nexus file.

Morphological data.-A large number of morphological and non-sequence characters, as reported in the literature and based on personal observation, were considered for this analysis. These included characters taken from ultrastructural studies of antheridia, spermatozoid development, and the gametophyte-sporophyte junction; developmental and SEM studies of protonema, gemmae, rhizoids, and conducting cells; light microscope studies of stem, leaf, rhizoid, sporophyte and peristome anatomy, and structure. Characters were excluded for several reasons 1) where the feature and its variation was insufficiently known to delimit the character and states; 2) where the character was well understood, but was either invariant or polymorphic at the taxonomic level under consideration, or 3) where insufficient data were available for a large proportion of the taxa included in this study. Many of the spermatogenesis characters used by Garbary et al.
(1993) and Garbary and Renzaglia (1998) were not included in this study. These characters were primarily relevant to the question of the relationships of the green plants and were either invariant within the mosses, or data were only available for a small proportion of the taxa involved in this study. Characters and states used for this phylogenetic analysis are listed and described in Appendix 1 , with references to the primary literature. Data were compiled using MacClade 3.06 (Maddison \& Maddison 1992) and the matrix is presented in Table 2.

Phylogenetic analyses.-Phylogenetic analyses were performed using PAUP* 4.0b2 (Swofford 1999) on an Apple Power Macintosh G3 (266 MHz-64MB RAM). Regions of ambiguous alignment and incomplete data (e.g., at the beginning and ends of sequence regions) were identified and excluded from further analyses. In the morphological data set, a large amount of data were missing due to the technical constraints inherent in many of the morphological characters. This prevented analysis of the full taxon set for the morphological data alone. Consequently three data sets were employed for the analyses a) sequence data alone including all taxa; b) morphological data alone including only a subset ("morph") of the taxa; and c) both sequence and morphological data for all taxa (with some missing data).

For each of these data sets, the following parsimony analyses were performed, with uninformative characters excluded. All characters were given equal weight, gaps in the sequence alignment were treated as missing data, all morphological characters were unordered, molecular sites with multiple states were coded as uncertainties, and branches were collapsed when the maximum branch length equaled zero during the branch swapping procedure. For each data set, a heuristic search was performed with 1,000 replicates (stepwise random taxon addition) and tree bisection and reconnection (TBR) branch-swapping. All the equally most-parsimonious solutions were saved.

For the molecular and combined data sets, branch support was calculated with the bootstrap method employing 1,000 replicates with the same options as for the heuristic search except that fewer replicates (100) of the random taxon addition were used. For the morphological data set, "morph" bootstrap support for branches was calculated using 10,000 bootstrap replicates, but each with a single random taxon addition replicate and with MULPARS off. Decay indices for branches were calculated using reverseconstraint trees (Baum et al. 1994) aided by the program AutoDecay 3.0 (Eriksson \& Wikström 1995), with each heuristic search consisting of ten replicates of random sequence addition to the starting tree. The $g_{1}$ statistic (Huelsenbeck 1991) was calculated for each data set based on the tree length frequency distribution of 50,000 random trees to test for the presence of phylogenetic signal in the data set.

\section{RESULTS}

The combined molecular data set (18S/rps4/ $\operatorname{trn} \mathrm{L}-\operatorname{trn\mathrm {F}} / r b c \mathrm{~L})$. - Following alignment, the sequence data consisted of 5,223 positions (2,018 18S, $719 r p s 4,1,102 t r n \mathrm{~L}-\mathrm{F}$, and 1,384 rbcL). Of the 1,039 parsimony-informative characters, 209 (20\%) were 18S, $272(26 \%)$ were $r p s 4,102(9.8 \%)$ were $t r n \mathrm{~L}-\mathrm{F}$, and 456 (44\%) were $r b c \mathrm{~L}$. For some taxa one or more sequences were not available (Table 1). The frequency distribution of tree lengths 


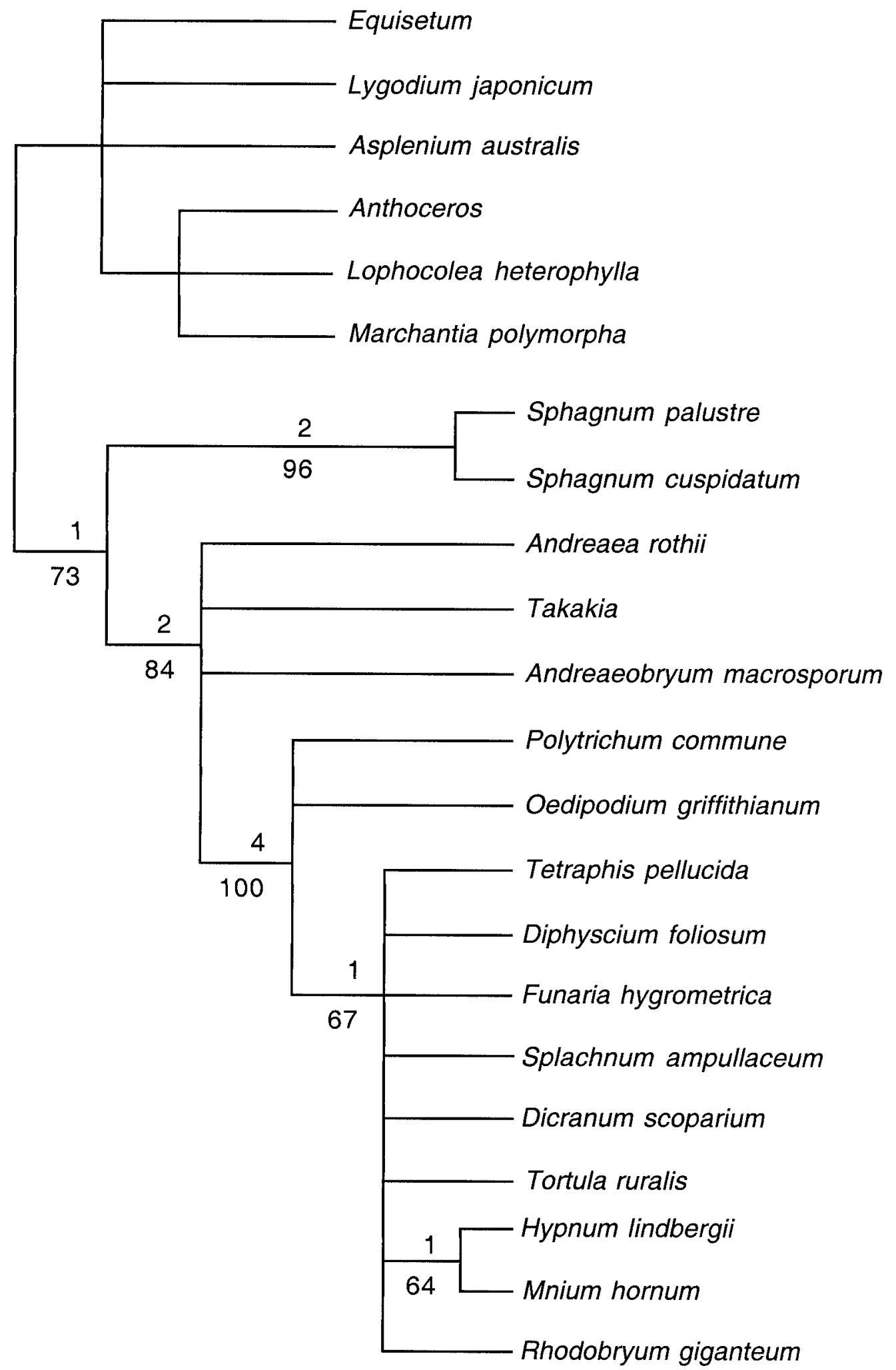

FIgURE 2. Strict Consensus of 12,010 MPTs (Length 87, CI $=0.839$, RI $=0.913$ ) found by parsimony analysis of morphological data for taxon subset "morph" (see Table 2). All characters were unordered and weighted equally. Bootstrap percentages (10,000 replicates, MULPARS off) shown below branches, decay indices above branches. 
for 50,000 randomly generated trees was significantly left-skewed $\left(g_{1}=-0.583\right)$. Two most parsimonious trees (MPTs) were found with lengths of $4,651(\mathrm{CI}=0.359, \mathrm{HI}=0.641, \mathrm{RI}=0.456, \mathrm{RC}$ $=0.164$ ). The strict consensus tree (i.e., including only groups found in $100 \%$ of trees) is shown in Figure 1, with bootstrap values $>50 \%$ shown below branches and decay indices shown above branches. Individual bootstrap analyses of each of the four individual sequence data sets showed no conflicting clades, with the exception that $\operatorname{trn} \mathrm{L}-\operatorname{trn} \mathrm{F}$ sequence data placed Takakia with Haplomitrium.

The morphological data set.-A total of 41 characters were included in the morphological data set (Appendix 1 and Table 2). The frequency distribution of tree lengths for 50,000 randomly generated trees was significantly left skewed $\left(g_{1}=\right.$ -0.772 ). Due to the large amounts of missing data it was impossible to run PAUP* to completion with all taxa included. A subset "morph" of the taxa included 22 exemplars for which character information was more complete (in Table 2 these taxa are indicated with $*$. For these taxa, 39 characters were parsimony informative. When the subset "morph" was analyzed 12,010 MPTs were found, with length $87(\mathrm{CI}=0.839, \mathrm{HI}=0.161, \mathrm{RI}=$ $0.913, \mathrm{RC}=0.766)$. The strict consensus tree is shown in Figure 2. Bootstrap values are shown below branches and decay indices are shown above branches.

The combined sequence and morphological data set.-This data set consisted of 5,267 characters of which 1,080 were parsimony informative. The frequency distribution of 50,000 randomly generated trees was significantly left skewed $\left(g_{1}=-0.598\right)$. Four MPTs were found, of which two were identical with those found using the sequence data alone, and differing only in the placement of small distal clades. The trees were 4,760 steps ( $\mathrm{CI}=$ $0.366, \mathrm{HI}=0.633, \mathrm{RI}=0.475, \mathrm{RC}=0.174)$. The strict consensus tree is shown in Figure 3, with bootstrap values $>50 \%$ shown below branches and decay indices shown above branches.

Tree topologies. - The two trees found by analysis of the sequence data differed only in the positions of two clades of arthrodontous mosses. The strict consensus tree is shown in Figure 1, and the alternative topologies (c-d) in Figure 4. Bootstrap percentage values (BP) and the decay index (DI) showed strong support for several individual clades, but the relationships of many of the basal clades were weakly supported (Fig. 1). Analysis of the combined morphological and molecular data resulted in four trees, of which two were identical to those found by the molecular data alone, and two showed further alternatives in the position of the distal clades (Fig. 4a-b). The addition of the morphological data to the analysis resulted in increased support for many of the clades. The topology of the trees resulting from analysis of the molecular and combined data sets will be discussed below (Figs. 3-4) with reference to the distribution of morphological characters.

The results of the separate analyses of the molecular and the morphological data (for the 22 taxa in the subset "morph") were mostly compatible, with support for conflicting placements weak or ambiguous. In both trees, based on analysis of the molecular data, Takakia was placed with Sphagnum as sister group to the remaining mosses, with no significant bootstrap support, but a decay index of six. However, in all trees based on analysis of the morphological data, Takakia was placed with Andreaea and Andreaeobryum rather than with Sphagnum $(\mathrm{BP}=84$, DI $=2)$. In the combined data, the bootstrap value was greatly decreased but the decay index was greatly increased $(\mathrm{BP}=58, \mathrm{DI}=11)$. A clade of operculate mosses was strongly supported $(\mathrm{BP}=100, \mathrm{DI}=4)$ by the morphological data, and consisted of an unresolved trichotomy of Polytrichum, Oedipodium, and a clade of the remaining peristomate mosses. In the trees resulting from analysis of the molecular data, this clade was also well supported $(\mathrm{BP}=96$, DI $=2)$; even though the trichotomy was resolved, the branches were poorly supported with low decay indices and no significant bootstrap support. There was no resolution of the relationships of the remaining exemplars in the morphological analysis, except that Mnium and Hypnum were placed together with rather weak support $(\mathrm{BP}=64, \mathrm{DI}=1)$. Few morphological characters were included that were informative for the distal taxa, and in addition there was much denser taxon sampling in the molecular analysis; both factors may have contributed to improved resolution of the relationships of these taxa.

Morphological character optimization.-The morphological characters were optimized onto the consensus tree derived from analysis of the combined molecular and morphological data, and the distribution of the character states will be discussed with reference to Figure 3. Where the bootstrap

FIGURE 3. Strict Consensus of four MPTs (Length 4,760, CI $=0.366$, RI $=0.475$ ) found by parsimony analysis of combined morphological and $18 \mathrm{~S}, r p s 4, t r n \mathrm{~L}-t r n \mathrm{~F}$, and $r b c \mathrm{~L}$ sequence data for all taxa. All characters were unordered and weighted equally. Bootstrap percentages (1,000 replicates) shown below branches, decay indices above branches. 


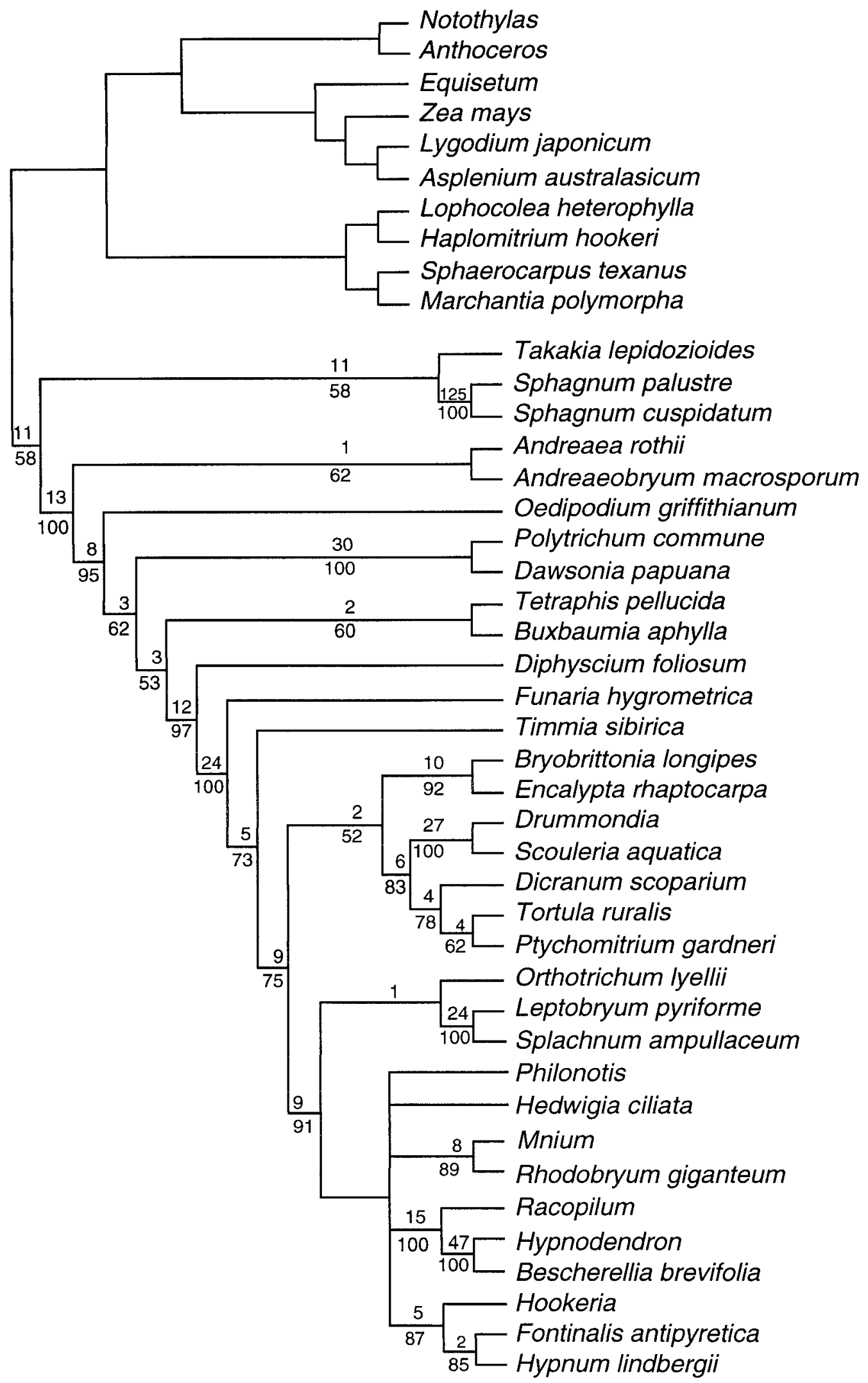


TABLE 2. Morphological data matrix used in the analysis of morphological data alone and in combination with the molecular sequence data. Taxa used for analysis of the morphological characters alone (taxon set "morph") are indicated with*.

\begin{tabular}{|c|c|c|c|c|}
\hline Taxon & $\begin{array}{r}1 \\
1234567890\end{array}$ & $\begin{array}{l}1111111112 \\
1234567890\end{array}$ & $\begin{array}{l}2222222223 \\
1234567890\end{array}$ & $\begin{array}{l}33333333344 \\
12345678901\end{array}$ \\
\hline Zea mays & & $-0 ?-$ & $00-0-?$ & $?-2-00$ \\
\hline *Equisetum hyemale & 2110320003 & $32-1 ?-0 ? 0$ & $-00-0-0$ & ?? $15-2-00$ \\
\hline *Lygodium japonicum & 3010320003 & $32-1 ?-00 ? 0$ & $-00-0-$ & ?? $15-2-00$ \\
\hline *Asplenium australasicum & 3010320003 & $32-1 ?-00 ? 0$ & $-00-0-$ & ?? $15-2-00$ \\
\hline Notothylas breutelii & 0101000011 & $1110 ?-00 ? 0$ & $-00-0-0$ & $0114-02-01$ \\
\hline *Anthoceros agrestis & 0101000011 & $1110 ?-00 ? 0$ & $-00-0-0$ & $0114-02-01$ \\
\hline *Lophocolea heterophylla & 0101202001 & $01000-0020$ & $-00-0-0$ & $10100000-11$ \\
\hline Haplomitrium hookeri & 0101001001 & $5 ? 100-0120$ & $-00-000$ & $131 ? 0000-11$ \\
\hline Sphaerocarpus texanus & 0101202001 & $01000-0 ? ? 0$ & $-00-0-0$ & $131 ? 0000-1 ?$ \\
\hline *Marchantia polymorpha & 0001202001 & $01000-0120$ & $-00-0-0$ & $13000000-11$ \\
\hline *Sphagnum palustre & 0010112212 & 2011000100 & $000-0100$ & $00130100-00$ \\
\hline *Sphagnum cuspidatum & 0010112212 & 2011000100 & $000-0100$ & $00130100-00$ \\
\hline *Takakia lepidozioides & 111011?01? & $? 00011012 ?$ & ???????002 & $10320111-00$ \\
\hline *Andreaea rothii & 1010112012 & $2001001 ? 01$ & $0 ? ?-1-0001$ & $10210110-00$ \\
\hline *Andreaeobryum macrocarpum & ????11???? & ????010?01 & $0 ? ?-1-0001$ & $10320111-00$ \\
\hline *Oedipodium griffithianum & 1????????? & ????101112 & 1101001112 & ??33?211000 \\
\hline *Polytrichum commune & 1110112112 & 2001101112 & 1103012112 & 10331211000 \\
\hline Dawsonia papuana & 1????12??? & ???? 101112 & 1103012112 & 10331211000 \\
\hline *Tetraphis pellucida & 1 10??2??? & ????101112 & 1111001112 & 12331211000 \\
\hline Buxbaumia aphylla & 1????????? & ????00? 112 & 1102001112 & 12331211000 \\
\hline *Diphyscium foliosum & 1????????? & ????101112 & 1112001112 & 12333211000 \\
\hline *Funaria hygrometrica & $1 ? 10 ? 111 ? ?$ & ????101112 & 1110001112 & 12333211000 \\
\hline Timmia sibirica & 1 ????????? & ????101112 & 1110001112 & ??33?211000 \\
\hline Bryobrittonia longipes & 1????????? & ????101112 & 1110001112 & ??333211000 \\
\hline Encalypta rhaptocarpa & 1 ?? ??????? & ????101112 & 1110001112 & ??333211000 \\
\hline *Dicranum scoparium & 1?1??????? & ????101112 & 1110001112 & $1 ? 332211000$ \\
\hline *Tortula ruralis & 1 ? 1 ?????? & ????101112 & 1110001112 & ??332211000 \\
\hline Ptycomitrium gardneri & 1????????? & ????101112 & 1110001112 & ??332211000 \\
\hline Scouleria aquatica & 1????????? & ????101112 & 1110001112 & ??332211?00 \\
\hline Drummondia prorepens & 1????????? & ????101112 & 1110001212 & ??332211?00 \\
\hline *Splachnum ampullaceum & 1?1??1???? & ????101112 & 1110001112 & ??333211000 \\
\hline Orthotrichum lyellii & 1????????? & ????101112 & 1110001112 & ??334211000 \\
\hline Hedwigia ciliata & 1????????? & ????101112 & 1110001112 & ??33?211000 \\
\hline Leptobryum pyriforme & 1????????? & ????101112 & 1110001112 & ??334211000 \\
\hline *Rhodobryum giganteum & 1???11?11? & 2???101112 & 1110001112 & 12334211000 \\
\hline *Mnium hornum & 1?1011?1?? & 2001101112 & 1110001212 & 12334211000 \\
\hline Philonotis fontana & 1????????? & ????101112 & 1110001112 & ??334211000 \\
\hline Hypnodendron dendroides & 1????????? & ????101112 & 1110001212 & ??334211000 \\
\hline Bescherellia brevifolia & 1????????? & ????101112 & 1110001212 & ??334211000 \\
\hline Racopilum tomentosum & 1????????? & ????101112 & 1110001212 & ??334211000 \\
\hline Hookeria lucens & 1????????? & ????101112 & 1110001212 & ??334211100 \\
\hline Fontinalis antipyretica & 1????????? & ????101112 & 1110001212 & ??334211100 \\
\hline *Hypnum lindbergii & 1110112112 & 2001101112 & 1110001212 & 12334211100 \\
\hline
\end{tabular}

percentage and decay index found by the analyses differs, the branch support values are shown separately (molecular/combined).

The relationships of the out-group taxa to the ingroup were poorly supported, but several characters were shared by the different groups. Hepatics and anthocerotes have nascent spermatids that are paired (char. 3: 0); have a diagonal spindle in the final mitotic division (char. 4: 1); lack sheets of endoplasmic reticulum around the plastid (char. 14: 0 , also lacking in Takakia); and possess elaters in the sporangium (char. 41: 1). Hepatics share with mosses the presence of an aperture in the spline under the anterior basal body, that may be open (char. 7: 1) or closed (char. 7:2); the presence of food-conducting cells (char. 18: 1); and wall labyrinths in the transfer cells on the sporophyte side of the placenta (char. 31: 1).

The moss exemplars, including Sphagnum, Takakia, Andreaea, and Andreaeobryum, form a monophyletic group $(\mathrm{BP}=-/ 62$, DI $=6 / 11)$. All share several characters associated with the developing spermatozoids: the anterior and posterior basal bodies are moderately staggered (char. 5: 1); the lamellar strip is positioned under the anterior basal body only (char. 6: 1); nuclear compaction proceeds at equal rates in both directions (char. 10: 2); the condensed chromatin forms a spiral central strand 
a

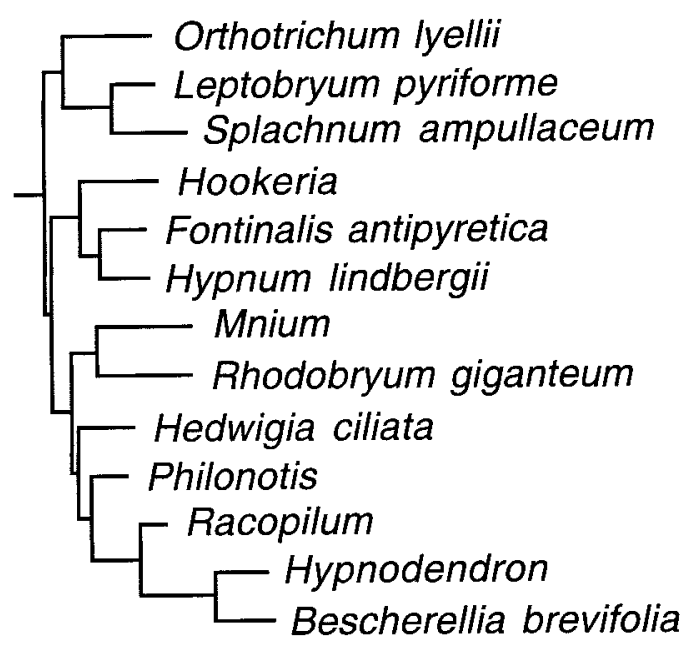

b

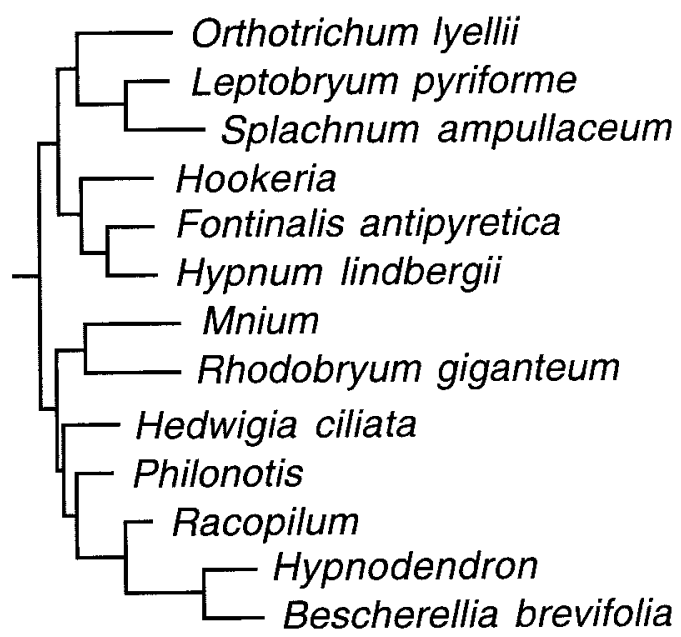

C

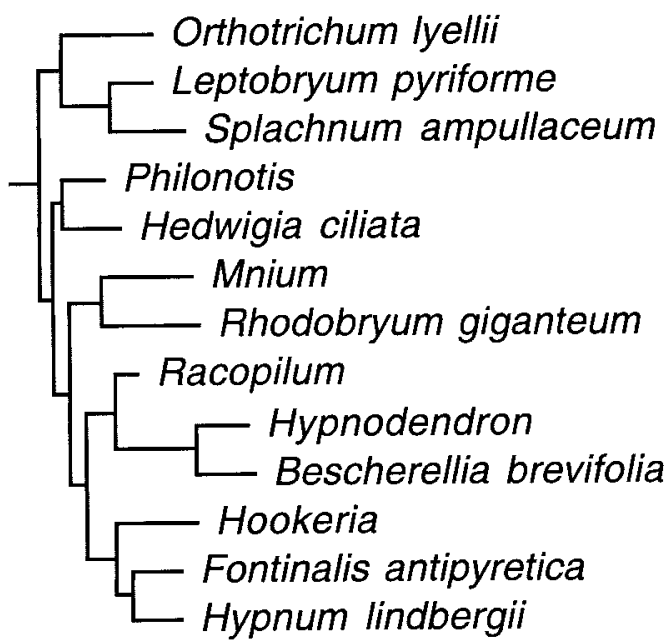

d

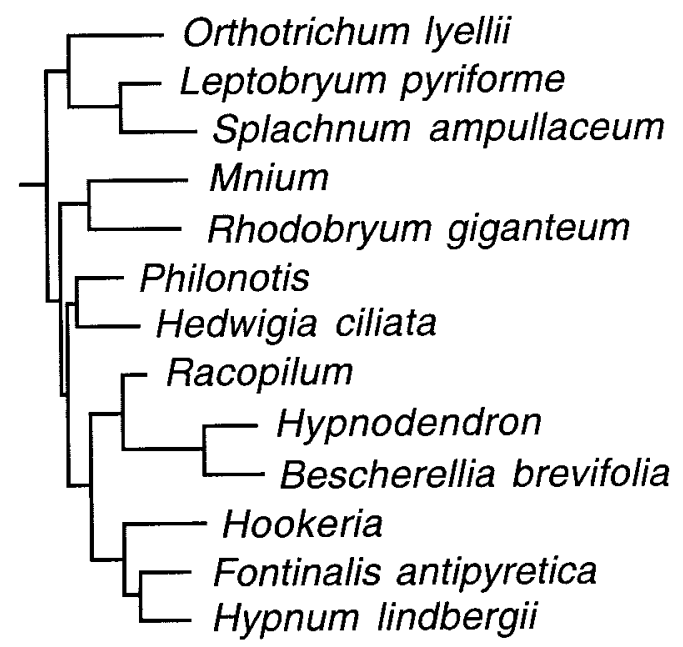

- 50 changes

FIGURE 4. Comparison of four distal clades found by parsimony analysis of combined morphological and $18 \mathrm{~S}$, $r p s 4$, trn L-trnF, and $r b c \mathrm{~L}$ sequence data for all taxa. Topologies a and $\mathrm{b}$ were also found by the molecular sequence data alone, topologies $\mathrm{c}$ and $\mathrm{d}$ were only found where the morphological and molecular data were combined. Branch lengths are proportional to the number of changes-note short internode lengths indicating few changes supporting some of the relationships shown. 
(char. 11: 2), and the plastids are located at the poles during mitotic divisions and determine the polarity of the divisions (char. 12: 0 ). A columella is present in all members of the clade (char. 36: 1/ 2). In Sphagnum, Takakia, Andreaea, and Andreaeobryum, the columella is dome-shaped and overarched by the sporogenous archesporium, whereas in all distal taxa the columella is cylindric. A seta formed through a brief phase of intercalary division ("seta meristem"- Crandall-Stotler 1984) is present in most mosses (char. 38: 1), but is absent in Sphagnum and Andreaea, both of which have the sporophyte raised on a gametophytic pseudopodium.

The relationships of Sphagnum and the non-operculate mosses (Takakia, Andreaea, Andreaeobryum) to each other, and to the peristomate mosses were resolved, with increased branch support resulting from the inclusion of the morphological data (but see discussion above). Takakia and Sphagnum were placed together as sister-group to the remaining mosses, but with relatively weak support (BP $=-158$, DI $=6 / 11$ ) and with no unique synapomorphies. Support for the placement of Andreaea with Andreaeobryum was reduced by the inclusion of morphological data $(\mathrm{BP}=71 / 62, \mathrm{DI}=2 / 1)$. The sister-group relationship between these taxa and the remaining in-group taxa (the operculate mosses) was strongly supported $(\mathrm{BP}=-/ 100, \mathrm{DI}=12 / 13)$. However, the distribution of morphological characters in these clades is somewhat ambiguous. The clade that includes Andreaeobryum, Andreaea, and all remaining moss exemplars, plus Takakia but excluding Sphagnum, has more than two antheridial operculum cells (char. 1: 1); possesses a conic foot (long tapering in most taxa, char. 33: 3, short conic in Andreaea 33: 2); and initial growth of the sporophyte is through limited division of an apical cell (char. 37: 1). This last character is inadequately described in Takakia, but is reported to be moss-like: "development. . closely parallels that of early stages in the Bryopsida" (Renzaglia et al. 1997). The calyptra in Sphagnum is limited to a basal collar (char. 30: 0) and as in Andreaea, Andreaeobryum, and the hepatics, the sporangium is retained in the epigonium until after meiosis has occurred, so that the calyptra is not formed until after meiosis (char. 30: 1). In all other mosses, including Takakia, the seta elongates and a calyptra is formed before meiosis (char. 30: 2). Mucilage papillae are present in Takakia and Andreaeobryum (char. 16: 1). Andreaea and Andreaeobryum both have multiseriate protonema (char. 20: 1) and parenchymatous protonemal appendages (char. 25: 1).

The operculate mosses, consisting of Oedipodium and the nematodontous and arthrodontous moss exemplars, form a strongly supported clade
$(\mathrm{BP}=96 / 95, \mathrm{DI}=2 / 8)$ and share a large suite of morphological characters. These taxa have "mosstype" antheridia: ovoid, with a domed cap and a short, broad, multicellular stalk (char. 15: 1) that terminate the axis on which they are formed (char. 29: 1). In Takakia, the antheridia have the same morphology, but are lateral (char. 29: 0). These taxa also have multicellular axillary hairs (char. 17: 1); hydroids consisting of elongate, thin-walled imperforate cells (char. 19: 1); filamentous protonema (char. 20: 2) with side branch initials (char. 21: 1), produce buds in response to cytokinins (char. 22: 1 ), and have side branch initials that develop platelike or multi-stratose protonemal appendages (char. 24: 1/2/3); thigmotropic rhizoids (char. 27: 1); acrogynous archegonia (char. 28: 1); operculate sporophyte dehiscence (char. 34: 3); and a cylindric columella (char. 36: 2).

The nematodontous mosses, with peristomes formed from multiple layers of whole or partial cells (char. 35: 1), form a paraphyletic grade basal to the clade of arthrodontous exemplars. The MPTs were fully resolved for this grade, but support for the relationships was rather weak, with the exception of the polytrichalean exemplars, Polytrichum and Dawsonia (BP $=100$, DI $=25 / 30)$. Of the characters included in this study, the polytrichalean exemplars have protonemal side branch initials that form clustered multistratose appendages (char. 24: 3 ) with gametophyte buds forming in their centers (char. 26: 1), and strong thigmotropism, resulting in the formation of rhizoidal "wicks" (char. 27: 2).

Although Buxbaumia and Tetraphis were placed together, this clade was only weakly supported (BP $=56 / 60$, DI $=3 / 2$ ) with no unique shared synapomorphies in the morphological characters, and a relatively short, shared branch in the molecular data (17 sites). These two taxa share with the arthrodontous mosses the presence of wall labyrinths in the transfer cells on the gametophyte side of the placenta (char. 32: 2).

The clade of arthrodontous mosses was strongly supported $(\mathrm{BP}=91 / 97, \mathrm{DI}=11 / 12)$ and the relationships of the basal taxa were resolved and well supported, with Diphyscium in the most basal position, followed by Funaria $(\mathrm{BP}=99 / 100$, DI = 22/24) and Timmia $(\mathrm{BP}=73$, DI $=5)$. These three genera have diplolepidous peristomes (char. 35: 3), but have a number of unique features that make comparisons difficult. The remaining arthrodontous exemplars were divided between two clades, one containing the diplolepidous taxa, and the other consisting of the haplolepidous taxa plus the Encalyptales. The sister-group relationship between these clades was moderately well supported $(\mathrm{BP}=$ 75, DI = 9).

The grouping of the two exemplars of the En- 
calyptales (Bryobrittonia and Encalypta) was well supported $(B P=93 / 92$, DI $=11 / 10)$. However, the support for the placement of these taxa as sistergroup to the haplolepidous exemplars was varied $(\mathrm{BP}=83 / 55$, DI $=2)$, and inclusion of morphological data markedly reducing the bootstrap support. The haplolepidous exemplars formed a monophyletic group $(\mathrm{BP}=-/ 83$, DI $=6 / 83)$ and relationships within the clade were resolved with moderate branch support. The sister-group relationship of Drummondia with Scouleria was strongly supported $(\mathrm{BP}=100, \mathrm{DI}=27)$. Dicranum was placed as sister $(\mathrm{BP}=76 / 78, \mathrm{DI}=5 / 4)$ to a clade consisting of Tortula and Ptychomitrium (BP $=65 / 62$, DI $=4)$.

The distal clade of diplolepidous mosses was well supported $(\mathrm{BP}=91$, DI $=9$ ) and included several groups, but resolution of the relationships within the clade differed and support was varied. Four alternative topologies for this clade were found in the analysis of the combined data (Fig. 4). Two of these topologies $(a-b)$ were found by the molecular data alone and show some similarities to Clade A and Clade B of Withey (1996). The other two topologies $(\mathrm{c}-\mathrm{d})$ reflect the influence of the morphological data, with the eubryalean pleurocarps sister to the meta-pleurocarps. In the consensus tree, based on the analysis of the combined data, a clade consisting of Leptobryum and Splachnum $(\mathrm{BP}=24, \mathrm{DI}=100)$ and Orthotrichum $(\mathrm{BP}=-, \mathrm{DI}=1)$ was placed as sister to the remaining taxa, but there was no branch support for this relationship. The eubryalean pleurocarps formed a well supported clade, with Racopilum as sister $(\mathrm{BP}=100, \mathrm{DI}=16 / 15)$ to Hypnodendron plus Bescherellia $(\mathrm{BP}=100$, DI $=48 / 47)$, but as yet few unique morphological synapomorphies have been identified for this clade. A clade composed of Rhodobryum and Mnium was well supported $(B P=88 / 89$, DI $=9 / 8)$, and in the analysis of the molecular data was placed sister to a clade composed of Hedwigia, Philonotis, and the eubryalean pleurocarps. However, the relationships of these taxa were scarcely supported (DI $=1)$ and in the analysis of the combined data, they were unresolved. The grouping of the meta-pleurocarps was moderately supported, with Hookeria sister $(\mathrm{BP}=78 / 87, \mathrm{DI}=4 / 5)$ to Hypnum plus Fontinalis $(\mathrm{BP}=89 / 85$, DI $=3 / 2)$.

\section{DISCUSSION}

The tree topologies found in this study are largely derived from the four sequences ( $r p s 4, \operatorname{trn} \mathrm{L}-\operatorname{trn} \mathrm{F}$ region, $18 \mathrm{~S}$, and $r b c \mathrm{~L}$ ) used for the molecular data. The morphological data were mostly congruent with the molecular data, but points of disagreement had little influence on the tree topology other than in a distal clade of diplolepidous taxa. This might be expected given the larger amount of information derived from the molecular data (1,039 informative sites) as opposed to the morphological data (41 informative characters). However, inclusion of the morphological data did affect the bootstrap and decay indices, in many cases indicating stronger support for many of the clades, especially those representing the most basal lineages.

The results of this study agree with much of the current consensus on the relationships and morphological features of the mosses. All mosses, including Sphagnum, Takakia, Andreaea, and Andreaeobryum are shown to form a monophyletic group with the nematodontous mosses forming a grade basal to the arthrodontous mosses. The plesiomorphic peristome arrangement of the arthrodontous mosses appears to be diplolepidous-opposite. The haplolepidous mosses form a monophyletic group that seems to be derived within a clade of diplolepidous-opposite taxa. The diplolepidous-alternate mosses form a monophyletic group that includes the Orthotrichales and the Splachnales, and is derived from a diplolepidous-opposite ancestor. There are two major clades of pleurocarpous mosses, the Eubryales and a clade composed of the Hookeriales, Hypnales, and Leucodontales (the meta-pleurocarps).

However, several questions are still not satisfactorily resolved. The genus Sphagnum represents a lineage of presumed ancient origins with a highly derived and unique morphology and physiology. Many evolutionary events can be assumed to have occurred over the course of this long history, both in the form of nucleotide substitutions and in the occurrence and fixation of morphological novelties. The group is usually recognized as a separate class (Sphagnopsida - Crum \& Anderson 1981; Vitt et al. 1998), and the relationship to other mosses is still obscure. Until recently there was no known close relative, however, the unusual species Ambuchanania leucobryoides now appears to be the sister-group to Sphagnum (Shaw 2000), and inclusion of sequence data from this species may allow improved resolution of the relationship of Sphagnum with the other mosses.

The sequence data place Takakia with Sphagnum, although these genera share few morphological similarities other than those common to the other basal moss lineages. Many of the morphological characters would indicate that Takakia is more closely related to Andreaeobryum or even the operculate mosses, but constraining any of the alternative arrangements of these taxa results in trees from 26 to 44 steps longer (though this was not tested for significance). Possible reasons for the placement 
of Takakia with Sphagnum include artifacts derived from analytical problems (e.g., long branch attraction, Felsenstein 1978). However, this placement may reflect evolutionary events, such as the reversal of morphological features in the ancestor of Sphagnum that are otherwise characteristic of Takakia or the other mosses; or parallel gains in Sphagnum and other basal taxa. The relationships of the three genera currently placed in the Andreaeopsida (Takakia, Andreaea, and Andreaeobryum) are also still unclear, and evidence from the morphological data as currently understood is conflicting. Both Andreaea and Sphagnum lack a seta meristem and have the sporophyte elevated on a gametophytic pseudopodium. It seems unlikely that the pseudopodium is homologous in these two taxa given the morphological dissimilarities (Murray 1988), and this is supported by the placement of these taxa in separate clades. The seta meristem was therefore either lost in parallel in Sphagnum and Andreaea, or was gained in Takakia, Andreaeobryum, and the ancestor of all other mosses. In Takakia, the presence of a seta meristem, the long tapering conic foot in the sporophyte, the timing of meiosis after elongation of the seta, and the development of a calyptra would all indicate a closer relationship to the peristomate mosses than to Sphagnum or Andreaea. The transverse (operculate) sporophyte dehiscence in Sphagnum may be independent from that seen in other mosses, or it may represent a synapomorphy for all mosses, with parallel gain of longitudinal dehiscence occurring in Takakia, Andreaea, and Andreaeobryum. Both Andreaeobryum and Takakia possess mucilage hairs, but there are sufficient morphological dissimilarities to suggest that these hairs may not be homologous.

In these analyses, the nematodontous mosses formed a paraphyletic grade, with Oedipodium as the most basal exemplar. The sporophyte of Oedipodium is operculate, with a circular line of dehiscence, but lacks a peristome. Little is known for this taxon about the ontogeny of the sporophyte or the patterns of division in the cells that would normally form the peristome, but further information may provide useful insights into early peristome evolution.
The three basal exemplars in the arthrodontous mosses (Diphyscium, Funaria, and Timmia) each have unusual peristomes, with several features that are not readily related to those in other taxa (Brassard 1979; Shaw et al. 1987, 1989a). However, the basic pattern of development of the arthrodontous peristome has been well understood for some time (Blomquist \& Robertson 1941; Edwards 1979, 1984; Shaw \& Anderson 1988; Shaw et al. 1987, $1989 a, b)$. The arthrodontous peristome is formed from the cell walls between concentric circles of cells in the ampithecium: the Inner Peristome Layer (IPL), Primary Peristome Layer (PPL) and Outer Peristome Layer (OPL). Three basic peristome "types" have long been recognized in the arthrodontous mosses: diplolepidous-opposite, diplolepidous-alternate, and haplolepidous. In diplolepidous taxa, the cell walls from all three rings of cells are involved, resulting in the formation of a peristome consisting of an exostome and an endostome. In the "opposite" or Funaria-type, the anticlinal walls of the IPL and the PPL are almost perfectly aligned (co-radial), so the endostome segments and the exostome teeth are opposite each other. In the "alternate" or Bryum-type, the anticlinal divisions in the IPL are asymmetric, and together with later shifts in the position of the IPL cells results in the placement of the endothecium segments alternating with the exostome teeth (Shaw et al. 1989a). In haplolepidous taxa, the OPL and periclinal PPL walls are not thickened (or the thickenings are resorbed) so that normally only the endostome is seen at maturity. However, in some haplolepidous taxa an outer ring may be seen, which may represent a rudimentary exostome, but has frequently been referred to as a prostome or properistome (Edwards 1984; Shaw et al. 1989b) that is, derived from an additional, external, ring of cells.

These "types" provide a useful general classification of the arthrodontous mosses into broad groups. Recent increase in knowledge of a range of peristome structures and the variation in the elements of these characters should now make it possible to develop more specific characters for use in cladistic analysis, but a full range of characters and states depends in part on information on the devel-

FIGURE 5. A-D. Andreaea rupestris cultured in vitro. - A. Germinating spore producing unbranched filaments of short cells. - B. Appendages from older protonema. Note they lack side branch initials and are thick-walled. - C. Young gametophore $(\mathrm{g})$ emerging from the center of a mass of filaments. - D. Gametophore $(\mathrm{g})$ emerging from the end of a filament-covered axis. In transverse-section such axes are virtually identical to the juvenile axes found in Andreaeobryum (see Fig. 1F). In Andreaea the filaments are restricted to germinating spores and juvenile axes; rhizoids are absent from adult gametophores. - E-G. Andreaeobryum (herbarium specimens from A. R. Perry). - E. Filaments from a juvenile axis. - F. Transverse sections through three juvenile axes (arrowed). These are much smaller and comprise fewer cells in transverse-section than the mature stems illustrated in $\mathrm{G}$. Bar lines. A-B $=20 \mu \mathrm{m}, \mathrm{C}-\mathrm{G}=50$ $\mu \mathrm{m}$. 

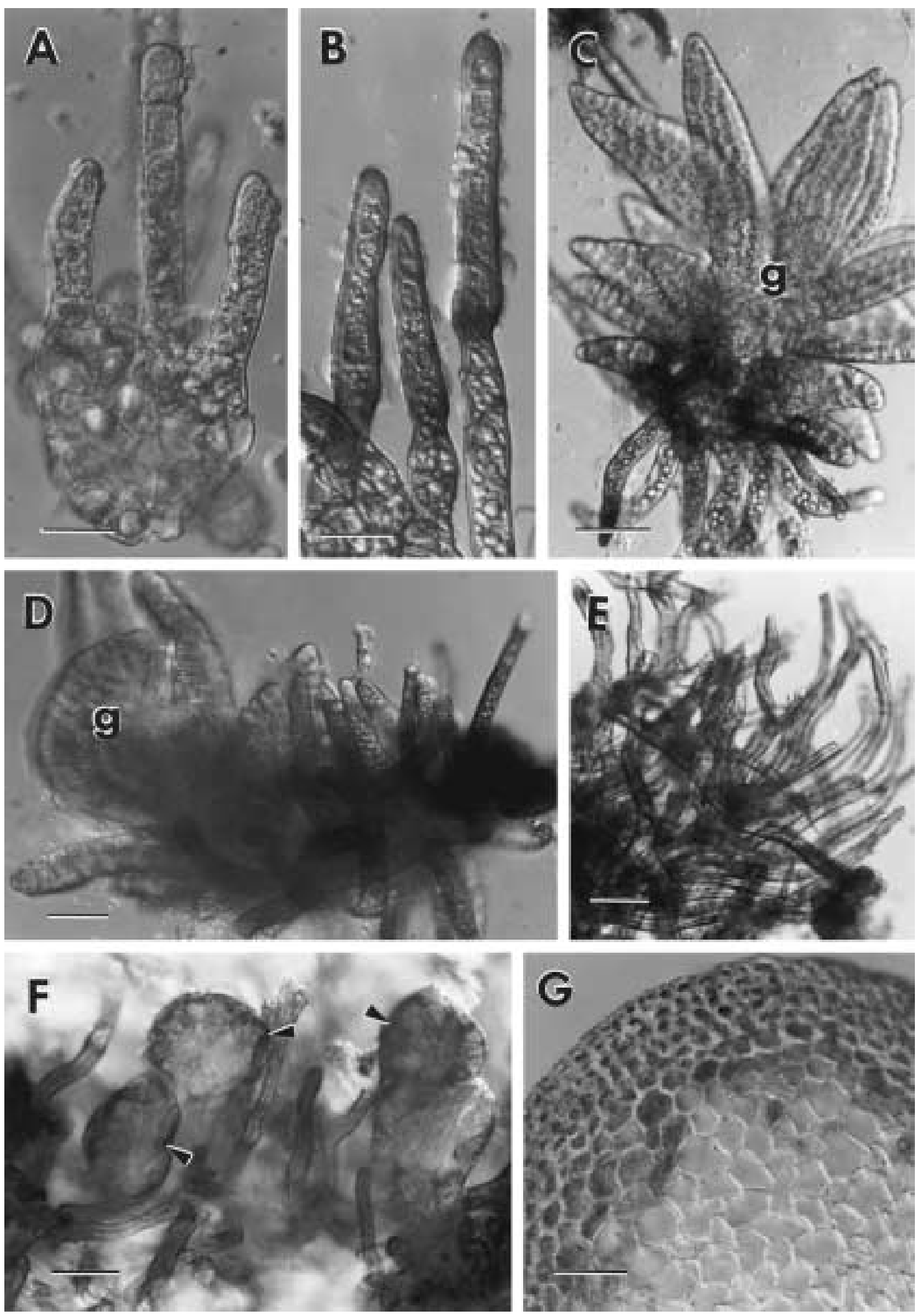
opmental anatomy of the peristomes from a wider range of taxa than has been studied so far.

However, existing studies have thrown light on the relationships of some taxa, in particular, supporting the hypothesis that the haplolepidous mosses are derived from ancestors with diplolepidousopposite peristomes. For example, Shaw et al. (1987) showed that Diphyscium has both an exostome and an endostome, with a cell ratio of 4:2:34 , and with cells that are co-radial. This cell ratio overlaps that typical of haplolepidous taxa, and the principle anticlinal walls of the PPL and IPL in haplolepidous mosses are also aligned (Edwards 1979). The peristome morphology in the Encalyptales varies in the different species of the family, but has been shown to be essentially diplolepidousopposite (Edwards 1984). The results of the current study place the exemplars from the Encalyptales as sister to the haplolepidous mosses, a position that has been suggested before and that is supported by a number of authors (see discussions by Shaw et al. 1987; Zander 1993). In a recent study of the Orthotrichales, Goffinet et al. (1998), using $r b c \mathrm{~L}$ sequence data, placed Encalypta procera with a clade of haplolepidous mosses. Other problematic taxa, several of which were previously placed in the Orthotrichales and in which the peristomes are reduced or missing, have also been placed with haplolepidous taxa by analyses using sequence data (Goffinet et al. 1998; Hedderson et al. 1998).

The relationships of taxa with diplolepidous-alternate peristomes to several groups with diplolepidous-opposite peristomes have still not been satisfactorily resolved. In the Splachnales and Orthotrichales, the "opposite" peristome configuration appears to be present, at least in some taxa. However, in this and other analyses, the exemplars for these taxa are placed with Leptobryum, in which the peristome is clearly diplolepidous-alternate with keeled endostome, cilia, and other features associated with this peristome type. In many of the Orthotrichales, the "alternate" configuration is seen, but the endostome segments are normally unkeeled, and cilia are unknown (Vitt 1984). With the taxa at hand it is not possible to say whether the "opposite" configuration represents the plesiomorphic state within this clade. This would necessitate hypothesizing parallel gain of the "alternate" configuration in both the Orthotrichales and Leptobryum, and of cilia and keeled segments in Leptobryum. An alternative would be that the common ancestor of this clade had the "alternate" configuration, with parallel reversals to the "opposite" configuration.

The evolution of perichaetia terminating lateral modules seems to have occurred a number of times in widely separated taxonomic groups, including Drummondia, some members of the Mniaceae, some genera of the Orthotrichales, the eubryalean pleurocarps, and the meta-pleurocarps. Even the more specialized form of this character, pleurocarpy, in which archegonia terminate very reduced lateral modules, appears to have evolved at least twice, in the eubryalean pleurocarps and in the meta-pleurocarps. Although the clade of meta-pleurocarps is strongly supported, a few morphological characters have been identified as restricted to these taxa. The homogenous costa of Hedenäs (1994) is one such character. Another character that may prove informative is the branching pattern of the rhizoids originating from the abaxial leaf base, that branch only when in contact with a substrate (char. 39: 1). This character state is seen only within the meta-pleurocarps, but is not present in all taxa. The genus Racopilum, with its prostrate habit, has usually been placed in the Hypnales (Vitt 1984), but is placed with the eubryalean pleurocarps by this and other recent studies (De Luna et al. 1999; Newton \& De Luna 1999; Withey 1996). Support from the molecular data for this placement in the eubryalean pleurocarps (with the exemplars Bescherellia and Hypnodendron) was very strong, but as with the meta-pleurocarps, there are few evident morphological characters to unite this group, other than a robust, upright, tufted habit, and a tropical distribution.

In the last few years there have been a number of analyses that have addressed broad issues of phylogenetic relationships in the mosses, usually using either morphological or molecular data, but not both. Several of these analyses used only a single gene or a limited suite of morphological characters. The overlap in taxa included in these studies and in the current analysis is only partial, and the topologies found vary, in some cases disagreeing strongly, while in others the results closely parallel those seen here. However, a broad consensus is emerging from these studies.

In a study of the major groups of the land plants, Garbary and Renzaglia (1998) used 132 ultrastructural and anatomical characters from the gametophyte and sporophyte, and included eight moss exemplars. The topology found was almost identical to that found in the present study, except that Takakia was placed sister to the remaining moss exemplars, rather than to Sphagnum. When gametophyte data alone were analyzed, Takakia was placed basal to the moss exemplars, whereas when only sporophyte data were analyzed Sphagnum was placed as sister to all the green plants, while Takakia was placed as sister to the peristomate mosses.

Hedderson et al. (1998) included 20 moss exemplars in a study of the relationships of the land plants, using 18S rRNA. Maximum parsimony and maximum likelihood methods were used, with sup- 

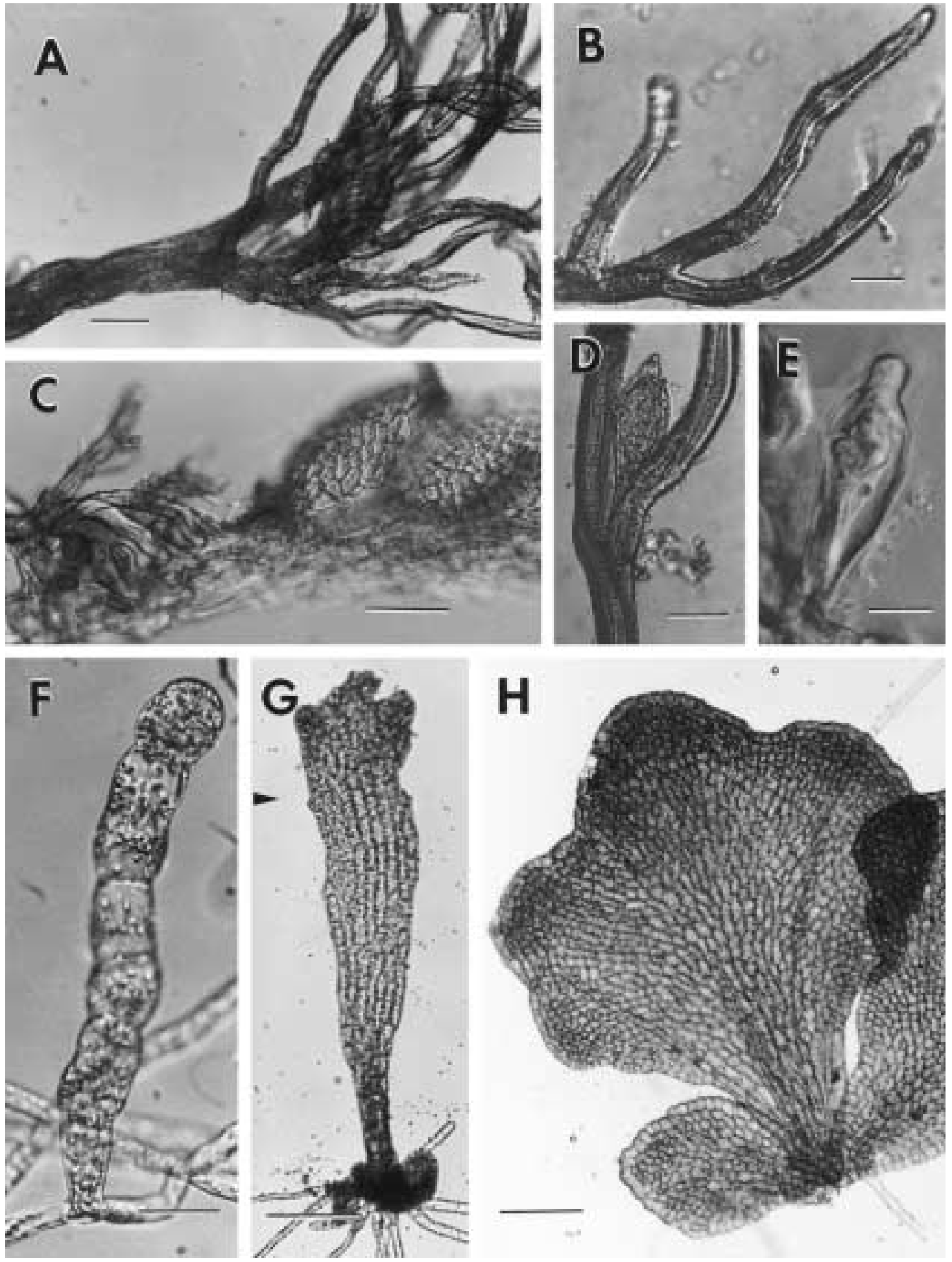

Figure 6. A-E. Andreaeobryum. - A. At the tips juvenile branches form a cluster of filaments. - B. Detail of the filaments. Note irregular branching, oblique septa, and thick walls. - C. Filaments restricted to the base of a mature stem. - D-E. Beaked mucilage papillae on the juvenile filaments (D) and a mature stem (E). Such papillae are never found on the protonema of other mosses. - F-H. Oedipodium griffithianum, cultured in vitro. - F. Horizontal filaments give rise to upright parenchymatous appendages. Similar structures are found in Tetraphis, Polytrichales, and Buxbaumiales. - G. Protonemal plate developing from a foliar gemma. - H. Massive protonemal plate like those found in Tetraphis. Bar lines: A, C, F $=50 \mu \mathrm{m} ; \mathrm{B}, \mathrm{D}=20 \mu \mathrm{m} ; \mathrm{E}=10 \mu \mathrm{m} ; \mathrm{G}, \mathrm{H}=200 \mu \mathrm{m}$. 
port for the nodes indicated by bootstrap values (3,000 replicates) and jacknife (10,000 replicates). A clade consisting of the nematodontous exemplars, plus Andreaea and Andreaeobryum and including Diphyscium, was placed as sister to the remaining mosses. A clade composed of Sphagnum and Takakia was sister to a clade of arthrodontous mosses, within which three clades were found (haplolepidae, Encalypta, diplolepidae), although the relationships between these clades were unresolved. The diplolepidous clade consisted of two orthotrichalean exemplars sister to a pectinate series of Splachnum, Bryum, Pleurozium, and Brachythecium. With the exception of the "nematodontous" clade, the topology was largely congruent with that found in the present study. This indicates a diplolepidous-opposite ancestor for the haplolepidae and the diplolepidous-alternate taxa, but leaves unresolved the question of whether the diplolepidousopposite configuration in orthotrichalean taxa and the Splachnales is plesiomorphic or derived.

The topology for the bryophytes found by Bopp and Capesius (1998) was also based on 18S rRNA, analyzed using phenetic neighbor-joining and parsimony analysis. In the bootstrap tree presented (Fig. 2b, based on 100 replicates) Sphagnum was basal to the other moss exemplars, no non-operculate or nematodontous mosses were included, and the two exemplars of the Funariales were sister to a clade containing the remaining taxa. This clade consisted of one group composed mostly of pleurocarps, and another composed of acrocarps, including both diplolepidous and haplolepidous taxa. Most bootstrap values shown were below 50\%, indicating no support for these relationships.

The monophyly of the Polytrichales and their relationship to other taxa were studied by Hyvönen (1998) using 18S, rbcL, and rps4 sequence data and morphological characters. The strict consensus of the trees based on all data, rooted on Sphagnum and Andreaea, showed the Polytrichales to be a monophyletic group. However, of the other taxa included, the relationships of the nematodontous taxa were unresolved, and the arthrodontous exemplars Funaria, Diphyscium, and Timmia formed a clade.

Two studies of the ordinal classification of mosses, based on unpublished results (Goffinet; Hedderson et al.), were reported by Vitt et al. (1998). The results of the Goffinet study were later published (Goffinet et al. 1998). In both the Goffinet and Hedderson studies, Sphagnum and Andreaea (and also Takakia) were used only as outgroups and their relationships were not considered. Goffinet et al. (1998) was primarily concerned with the relationships of the Orthotrichales, based on analysis of $r b c \mathrm{~L}$ sequence data. In the preferred topology, $\mathrm{Fu}$ naria was placed sister to a clade consisting of En- calypta and the other arthrodontous mosses. The haplolepidous exemplars were sister to a clade composed of diplolepidous taxa. In this latter clade, the exemplars from the Splachnaceae (Tayloria), with a "Funaria type" opposite peristome, were sister to the diplolepidous-alternate exemplars (Orthotrichaceae, Hedwigia, Mnium, and Abietinella). In an alternative topology (the most parsimonious, and published in Goffinet et al. 1998) Tayloria was sister to Orthotrichum. This topology optimized the peristome characters with the diplolepidous-alternate taxa and the haplolepidous taxa sharing a most recent common ancestor, and with the diplolepidous-opposite exemplar (Tayloria) derived from within the diplolepidous-alternate taxa. In the Hedderson study, which used a similar but rather broader range of taxa, and sequence data from $18 \mathrm{~S}$ nrDNA, the nematodontous taxa were placed sister to the arthrodontous taxa. In the arthrodonts, $F u$ naria was most basal and Timmia was placed sister to Encalypta and the other exemplars. The topology found in the distal taxa was similar to the preferred topology in Goffinet et al. (1998).

In a study that used $18 \mathrm{~S}, r p s 4$, and $\operatorname{trn} \mathrm{L}-\operatorname{trn} \mathrm{F}$ sequence data, Cox and Hedderson (1999) included a large number of diplolepidous mosses, using $\mathrm{Fu}$ naria and Timmia as outgroups. For the 40 species for which all three sequences were available, parsimony analysis found a monophyletic clade of the haplolepidous exemplars sister to diplolepidous exemplars. A clade composed of Encalypta and Bryobrittonia was the most basal lineage in the diplolepidae. Taxa with diplolepidous-alternate peristomes were found in two separate clades derived from ancestors with diplolepidous-opposite peristomes. A well supported (bootstrap 99, decay index 11) clade composed of the exemplars from the Splachnales included Meesia and Leptobryum, indicating either independent origin of the suite of peristome characters (for example, keeled endostome segments, and cilia) in this clade and in the ancestor of the other diplolepidous taxa, or loss of these characters in each member of the splachnalean grade. Similarly, the exemplars of the Orthotrichaceae, a family that includes some taxa with diplolepidous-opposite peristomes (Vitt 1984), was sister to Aulacomnium, requiring either independent origin of the "alternate" suite of characters in this taxon, or secondary loss of these characters in the orthotrichalean lineage. However, although individual clades were well supported, the relationships between them were not, so these questions should be regarded as unresolved. For 60 taxa, only sequence data from $r p s 4$ and $t r n \mathrm{~L}-\operatorname{trn} \mathrm{F}$ were available. Analysis of these data placed Encalypta, Bryobrittonia, and Scouleria with the out-group taxa. Additional taxa were included in the Lepto- 

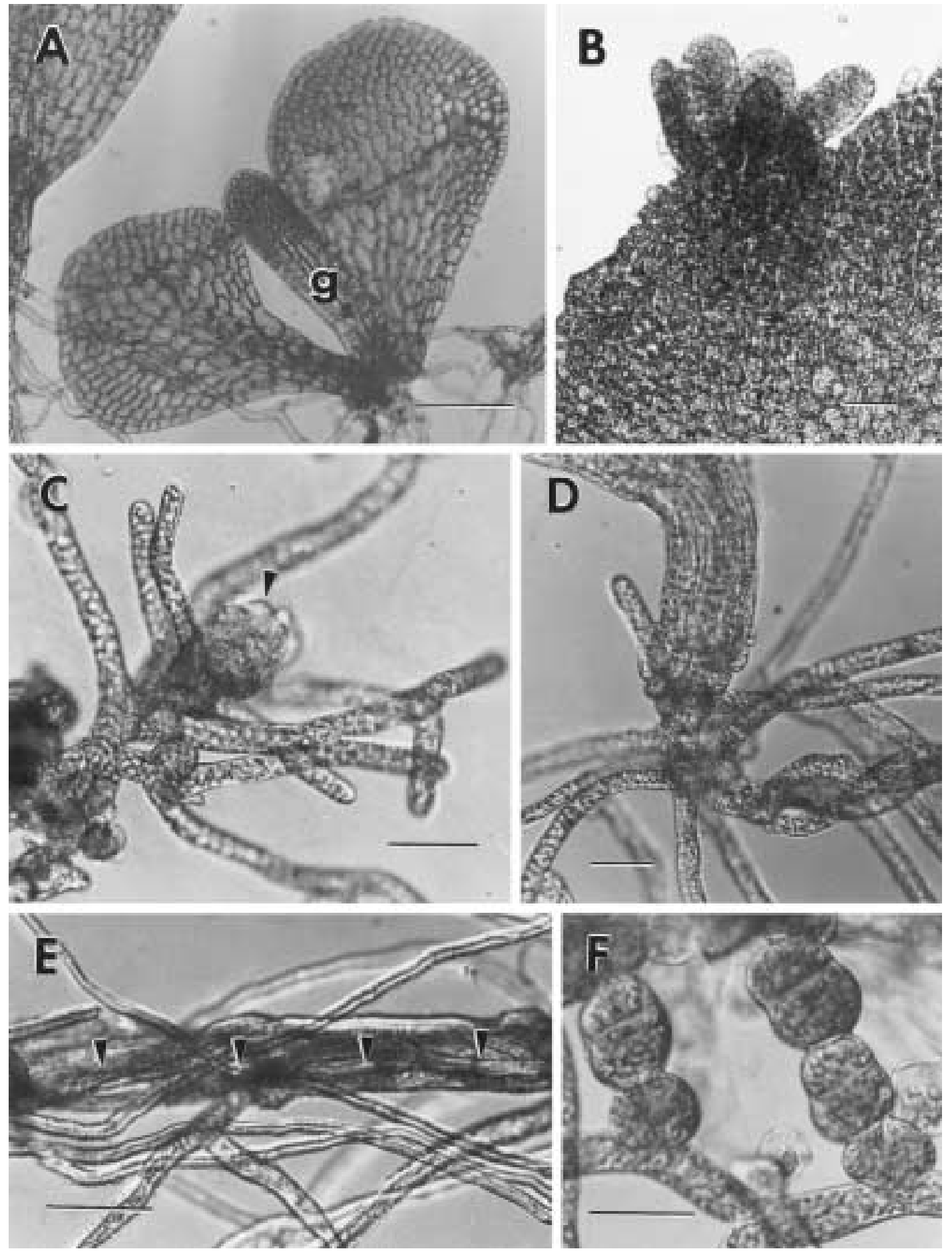

FIgURE 7. A-B. Oedipodium griffithianum. - A. Young gametophore (g) developing at the base of the plates, as seen in Tetraphis. - B. Super-numerous gametophores developing on a plate margin following treatment with kinetin. - C-E. Polytrichales. - C. Young Polytrichum commune gametophore (arrow) developing from the center of a rosette of filaments with bud formation along caulonemata. - D. Atrichum tenellum. Older gametophore in the center of a group of filaments. - E. Protonemal thigmotropism; a rope in Polytrichum formosum. A large central filament (position arrowed) is completely obscured by narrower side branches wound around it. - F. Protonemal gemmae formed along chloronemal side branches in Pottia bryoides. Bar lines: $\mathrm{A}=200 \mu \mathrm{m} ; \mathrm{B}=20 \mu \mathrm{m} ; \mathrm{C}-\mathrm{F}=50 \mu \mathrm{m}$. 
bryum clade and the Splachnaceae formed a clade rather than a grade. Four distal clades (Orthotrichales; Aulacomnium spp.; eubryalean pleurocarps; and meta-pleurocarps) were well supported, but the relationships between them were unresolved. It is evident from these analyses that increased sampling increased the strength of individual clades, but the reduced character information decreased resolution of the relationships between the clades.

In a study of the relationships of the Spiridentaceae, Withey (1996) used $r b c \mathrm{~L}$ sequences for a phylogenetic analysis that proposed the existence of two distinct clades (A and B) in the diplolepidous mosses. Clade A was well supported and contained the Spiridentaceae and other eubryalean pleurocarps, including Bescherellia, Hypnodendron, and Racopilum. Also included in this clade were exemplars of the Rhizogoniaceae, Mniaceae, and Bartramiaceae. Clade B contained representatives of the Hookeriales, Hypnales, and Leucodontales, and of the Bryaceae. These clades have provided the focus for several subsequent projects studying the evolution of pleurocarpy.

In one such project, $r b c \mathrm{~L}$ sequence data were used alone (De Luna et al. 1999) or in combination with morphological characters (Newton \& De Luna 1999). Using $r b c \mathrm{~L}$ data alone, the resulting topologies were similar to those found by Withey (1996). The Orthotrichales formed the most basal clade, and Splachnum was placed with Bryum and Leptobryum in a clade sister to Hedwigia and Clades A and B. The combined results of $r b c \mathrm{~L}$ sequence data and morphology (Newton \& De Luna 1999) were similar, but the Bartramiaceae, Mniaceae, Bryaceae, and Splachnaceae formed a clade sister to the pleurocarpous taxa, which included both eubryalean pleurocarps and meta-pleurocarps. Both these analyses indicate that the diplolepidousopposite Splachnum is derived within a clade of diplolepidous-alternate taxa, but the status of the diplolepidous-opposite members of the Orthotrichales remains unresolved. In both analyses, the Hookeriales were shown to be sister to a combined clade of Leucodontales and Hypnales.

In a study of the basal pleurocarp lineages, Hedenäs (1994) used a range of morphological characters. Resolution of the relationships was weak, but there was some indication that the Hypnales, Leucodontales, and Hookeriales form a monophyletic group, and that the Bartramiaceae and Mniaceae are associated with the eubryalean pleurocarps.

A number of features are apparent from these studies and the present analysis. Different analyses, using different data, are usually focused on the resolution of specific problems, but frequently produce results that are generally in agreement. Even though there is consensus on many points, several questions remain problematic. Resolution of the precise relationships of the basal lineages may require denser taxon sampling and additional information from some of the more technically demanding morphological characters. The paraphyly of the nematodontous taxa needs clarification. One of the most challenging questions may be the relationship of the diplolepidous-opposite taxa to the other arthrodontous mosses. The clades of meta-pleurocarps and eubryalean pleurocarps both seem undoubtedly monophyletic, but the relationships between these and other clades need further study.

\section{CONCLUSIONS}

The results of the present work, incorporating both morphological and molecular data, provide support for a broad consensus on the relationships of the major lineages of mosses, including the monophyly of the mosses as well as the relationships of the major groups. These results in part agree with the observations or results of other workers, based on morphological and/or molecular data. However, most previous work has addressed higher or lower level relationships, and few studies have specifically addressed the relationships among the major moss lineages.

Inclusion of the morphological data provides increased confidence in the phylogenetic hypotheses derived from the combined data, compared to hypotheses derived from the molecular data alone. These morphological data also provide a basis for study of morphological characters, by providing a phylogenetic context in which apparent similarities can be assessed.

The following general conclusions can be made based on the relationships and evolutionary patterns in the major lineages of the mosses (reflecting, in part, Vitt et al. 1998, p. 117):

1. All mosses, including Takakia, form a monophyletic group, and share a number of spermatozoid features.

2. The most basal lineage includes Sphagnum.

3. Andreaea, Andreaeobryum, and Takakia are basal to the nematodonts, but may each represent a separate lineage. The different forms of linear sporophyte dehiscence may not be homologous.

4. The operculate mosses include Oedipodium, the nematodonts, and the arthrodonts; these taxa share a number of features including moss-type antheridia, filamentous protonema, operculate sporophyte dehiscence, and a cylindric columella.

5. The nematodonts may be paraphyletic, and are basal to the arthrodonts. 
6. The basal lineages of the arthrodontous mosses, represented by Diphyscium, Funaria, and Timmia, have diplolepidous-opposite peristomes.

7. The taxa with diplolepidous peristomes are paraphyletic.

8. Taxa with a haplolepidous peristome (i.e., lacking an exostome at maturity and with the 2:3 arrangement of the PPL:IPL cells) form a monophyletic group, and are derived from an ancestor with a diplolepidous-opposite peristome.

9. The evolution of perichaetia terminating lateral axes has occurred repeatedly and the evolution of the special form of this character (pleurocarpy) has occurred at least twice.

\section{ACKNOWLEDGMENTS}

The authors gratefully acknowledge funding provided by the Museum Research Fund (MRF S007204) (to A. E. Newton (PI) \& C. J. Cox), and the Green Plant Phylogeny Research Co-ordination Group (Deep Green): DOE/NSF/ USDA Panel on Collaborative Research in Plant Biology "The Origins and Phylogeny of Green Plants: A Research Co-ordination Group," USDA grant 94-37105-0713, University of Tulsa, 1994-1999, PIs M. A. Buchheim, B. D. Mishler, and R. L. Chapman.

\section{Literature Cited}

Baum, D. A., K. J. Systsma \& P. C. Hoch. 1994. A phylogenetic analysis of Epilobium (Onagraceae) based on nuclear ribosomal DNA sequences. Systematic Botany 19: 363-388.

Bernhard, D. L. \& K. S. RenZaglia. 1995. Spermiogenesis in the moss Aulacomnium palustre. THE BRYOLOGIST 98: 52-70.

Blomquist, H. L. \& L. L. Robertson. 1941. The development of the peristome in Aulacomnium heterosticum. Bulletin of the Torrey Botanical Club 68: 569584.

Bopp, M. 1983. Developmental physiology of bryophytes, pp. 276-324. In R. M. Schuster (ed.), New Manual of Bryology, Vol. 1. Hattori Botanical Laboratory, Nichinan, Japan.

\& I. CAPESIUS. 1998. A molecular approach to bryophyte systematics, pp. 79-88. In J. W. Bates, N. W. Ashton \& J. G Duckett (eds.), Bryology for the Twenty-first Century. Maney Publishing and British Bryological Society, Leeds, U.K.

BRASSARD, G. R. 1979. The moss genus Timmia. 1. Introduction, and revision of $T$. norvegica and allied taxa. Lindbergia 5: 39-53.

Brown, R. C. \& Z. B. CARothers. 1986. Comparative studies of spermatogenesis in the Bryopsida. II. Blepharoplast morphology in Archidium tenerrimum Mitt. The BRyologist 89: 42-48.

Carothers, Z. B. \& R. C. Brown. 1985. Comparative studies of spermatogenesis in the Bryopsida. I. Blepharoplast morphology in Funaria hygrometrica Hedw. THE BRYOLOGIST 88: 325-332.

— \& J. G. DucketT. 1979. Spermatogenesis in the systematics and phylogeny of the Hepaticae, pp. 425446. In G. C. S. Clarke, \& J. G. Duckett (eds.), Bryophyte Systematics. Systematics Association Special Volume 14. Academic Press, London.
\& A. E. Rushing. 1988. Comparative morphology of the bryophyte blepharoplast. Advances in Bryology 3: 95-134.

- - \& R. C. BRown. 1997. The blepharoplast of the midstage spermatid of Andreaeobryum macrosporum (Bryophyta: Andreaeopsida). THE BRYOLOGIST 100: 440-447.

Cavers, F. 1910[1964]. The inter-relationships of the Bryophyta. New Phytologist Reprint No. 4. Dawsons, London.

Chase, M. W. \& A. V. Cox. 1998. Gene sequences, collaboration and analysis of large data sets. Australian Systematic Botany 11: 215-229.

Cox, C., B. Goffinet, A. E. Newton, A. J. Shaw, \& T. A. J. Hedderson. 2000. Phylogenetic relationships among the diplolepidous-alternate mosses (Bryidae) inferred from nuclear and chloroplast DNA sequences. THE BRyOLOGIST 103: 224-241.

\& T. A. J. Hedderson. 1999. Phylogenetic relationships among the ciliate arthrodontous mosses: evidence from chloroplast and nuclear DNA sequences. Plant Systematics and Evolution 215: 119-139.

Crandall-Stotler, B. 1984. Musci, Hepaticae and Anthocerotes - an essay on analogues, pp.1093-1129. In R. M. Schuster (ed.), New Manual of Bryology, Vol. 2. Hattori Botanical Laboratory, Nichinan, Japan.

Crum, H. A. \& L. E. Anderson. 1981. Mosses of Eastern North America. Columbia University Press, NY.

De Luna, E., A. E. Newton, A. Withey, D. Gonzalez \& B. D. Mishler. 1999. The transition to pleurocarpy: a phylogenetic analysis of the main diplolepidous lineages based on $r b c \mathrm{~L}$ sequences and morphology. THE BRYOLOGIST 102: 634-650.

DucketT, J. G. 1994. Studies of protonemal morphogenesis in mosses V. Diphyscium foliosum (Hedw.) Mohr. (Buxbaumiales). Journal of Bryology 18: 223-238.

\& P. R. BELL. 1977. An ultra-structural study of the mature spermatozoid of Equisetum. Philosophical Transactions of the Royal Society, B, Biological Sciences 227: 131-158.

— \& Z. B. CAROTHERs. 1979. Spermatogenesis in the systematics and phylogeny of the Musci, pp. 385-424. In G. C. S. Clarke \& J. G. Duckett (eds.), Bryophyte Systematics. Systematics Association Special Volume 14. Academic Press, London.

\& C. C. J. Miller. 1982. Comparative spermatology and bryophyte phylogeny. Journal of the Hattori Botanical Laboratory 53: 107-125

- \& - 1983. Gametogenesis, pp. 232-275. In R. M. Schuster (ed.), New Manual of Bryology, Vol. 1. Hattori Botancial Laboratory, Nichinan, Japan.

, P. Fletcher, H. W. Matcham, \& A. J. Russell. 2000. In vitro cultivation of bryophytes. (in press).

\& K. S. RenZaglia. 1986. The blepharoplast of Hypnum. Journal of Bryology 14: 375-385.

, A. M. Schmidt \& R. Ligrone. 1998. Protonemal morphogenesis, pp. 223-247. In J. W. Bates N. W. Aston \& J. G. Duckett (eds.), Bryology for the Twenty-first Century. Maney Publishing and British Bryological Society, Leeds, U.K.

Duff, R. J. \& D. L. Nickrent. 1998. Phylogenetic relationships of land plants using mitochondrial smallsubunit rDNA sequences. American Journal of Botany 86: 372-386.

EDWARDS, S. R. 1979. Taxonomic implications of cell patterns in haplolepidous moss peristomes, pp. 317-346. In G. C. S. Clarke \& J. G. Duckett (eds.), Bryophyte 
Systematics. Systematics Association Special Volume 14. Academic Press, London.

1984. Homologies and inter-relationships of moss peristomes, pp. 658-695. In R. M. Schuster (ed.), New Manual of Bryology, Vol. 2. Hattori Botanical Laboratory, Nichinan, Japan.

Eriksson, T. E. \& N. WiKstrÖM. 1995. AutoDecay, ver. 3.0 (program distributed by the authors). Department of Botany, Stockholm University, Stockholm.

Felsenstein, J. S. 1978. Cases in which parsimony and compatibility will be positively misleading. Systematic Zoology 27: 401-410.

Garbary, D. J. \& K. S. RenZaglia. 1998. Bryophyte phylogeny and the evolution of land plants: evidence from development and ultra-structure, pp. 45-64. In J. W. Bates, N. W. Aston \& J. G. Duckett (eds.), Bryology for the Twenty-first Century. Maney Publishing and British Bryological Society, Leeds, U.K.

\& $\longrightarrow$ J. G. DucketT. 1993. The phylogeny of land plants: a cladistic analysis based on male gametogenesis. Plant Systematics and Evolution 188: 237-269.

Goffinet, B., R. J. BAyer \& D. H. VitT. 1998. Circumscription and phylogeny of the Orthotrichales (Bryopsida) inferred from $r b c \mathrm{~L}$ sequence analyses. American Journal of Botany 85: 1324-1337.

— \& C. J. Cox. 2000. Phylogenetic relationships among basal-most arthrodontous mosses (Bryopsida) with special emphasis on the evolutionary significance of the Funariinae. The BRYOlOGIST 103: 212-223.

Goode, J. A., A. D. Steade \& J. G. Duckett. 1992. Protonemal morphogenesis of the moss Tetraphis pellucida Hedw. in culture and in the wild. Annals of Botany 70: $519-530$.

$\longrightarrow$ - $1993 a$. Experimental studies of protonemal morphogenesis in Sphagnum: The role of growth regulators and the cytoskeleton. Advances in Bryology 5: 129-151.

$\longrightarrow$ - $\&-1993 b$. Redifferentiation of moss protonema: an experimental and immunofluorescence study of brood cell formation. Canadian Journal of Botany 71: 1510-1519.

Hedderson, T. A. J., R. L. Chapman \& C. J. Cox. 1998. Bryophytes and the origins and diversification of the land plants: new evidence from molecules, pp. 65-78. In J. W. Bates, N. W. Aston \& J. G. Duckett (eds.), Bryology for the Twenty-first Century. Maney Publishing and British Bryological Society, Leeds, U.K.

HEDENÄs, L. 1989. Axillary hairs in pleurocarpous mosses-a comparative study. Lindbergia 15: 166-180.

. 1994. The basal pleurocarpous diplolepidous mosses-a cladistic approach. THE BRYOLOGIST 97: $225-243$.

HuelsenbeCK, J. P. 1991. Tree-length distribution skewness: an indicator of phylogenetic information. Systematic Zoology 40: 257-270.

Hyvönen, J., T. A. J. Hedderson, G. L. Smith Merrill \& S. Koskinen. 1998. On phylogeny of the Polytrichales. The Bryologist 101: 489-504.

Judd, W. S., C. S. Campbell, E. A. KellogG, \& P. F. SteVens. 1999. Plant Systematics. A Phylogenetic Approach. Sinauer Associates, Inc., Sunderland, MA.

Kenrick, P. \& P. R. Crane. 1997. The Origin and Early Diversification of the Land Plants: A Cladistic Study. Smithsonian Institution, Washington D.C.

Koponen, T. 1968. Generic revision of the Mniaceae Mitt. (Bryophyta). Annales Botanici Fennici 5: 117-151.

La Farge, C., B. D. Mishler, J. Wheeler, D. Wall, K. Johannes, S. Schaffer \& J. Shaw. 2000. Phylogenetic relationships within the haplolepidous mosses. THE BRYOLOGIST 103: 257-276.

Ligrone, R. \& J. G. DuCKetT. 1994. Cytoplasmic polarity and endoplasmic microtubules associated with the nucleus and organelles are ubiquitous features of foodconducting cells in bryoid mosses (Bryophyta). New Phytologist 127: 601-614.

— \& K. S. Renzaglia. 1993. The gametophyte-sporophyte junction in land plants. Advances in Botanical Research 19: 231-317.

$\longrightarrow,-$ \& 2000. Conducting tissues and phyletic relationships of bryophytes. Philosophical Transactions of the Royal Society of London, series B in press.

MadDison, W. P. \& D. R. MAdDison. 1992. Analysis of phylogeny and character evolution. Version 3.0. Sinauer Associates, Inc., Sunderland, MA.

MishleR, B. D. 1994. Cladistic analysis of molecular and morphological data. American Journal of Physical Anthropology 94: 143-156

\& S. P. Churchill. 1984. A cladistic approach to the phylogeny of the bryophytes. Brittonia 36: 406424.

Murray, B. M. 1988. Systematics of the Andreaeopsida (Bryophyta): Two orders with links to Takakia. Beiheft zur Nova Hedwigia 90: 289-336.

NeIDHART, H. V. 1979. Comparative studies of sporogenesis in bryophytes, pp. 251-316. In G. C. S. Clarke \& J. G. Duckett (eds.), Bryophyte Systematics. Systematics Association Special Volume 14. Academic Press, London.

Newton, A. E. \& E. De Luna. 1999. A survey of morphological characters for phylogenetic study of the transition to pleurocarpy. THE BRYOLOGIST 102: 651682

Paolillo, D. J. JR., G. L. Kreitner \& J. A. Reighard 1968a. Spermatogenesis in Polytrichum juniperinum. I. The origin of the apical body and the elongation of the nucleus. Planta 78: 226-247.

$\longrightarrow,-$ 1968b. Spermatogenesis in Polytrichum juniperinum. II. The mature sperm. Planta 78: 248-261.

Proskauer, J. 1962. On Takakia, especially its mucilage hairs. Journal of the Hattori Botanical Laboratory 25: 217-223.

Renzaglia, K. S. \& J. G. Duckett. 1987. Spermatogenesis in Blasia pusilla: from young antheridium to mature spermatozoid. THE BRYOLOGIST 90: 419-449.

$-\&-$ 1988. Different developmental processes underlie similar spermatozoid architecture in mosses, hepatics and hornworts. Journal of the Hattori Botanical Laboratory 64: 219-236.

$-\&-1991$. Towards an understanding of the differences between the blepharoplasts of mosses and liverworts, and comparisons with hornworts, biflagellate lycopods and charophytes: a numerical analysis. New Phytologist 117: 187-208.

$\longrightarrow$, K. D. MCFarland \& D. K. Smith. 1997. Anatomy and ultrastructure of the sporophyte of Takakia ceratophylla (Bryophyta). American Journal of Botany 84: $1337-1350$.

Rogers, S. O. \& A. J. Bendich. 1994. Extraction of total cellular DNA from plants, algae and fungi, D1: 1-8. In S. B. Gelvin \& R. A. Schilperoot (eds.), Plant Molecular Biology Manual. Klewer Academic Publishers, London.

Roth, D. 1969. Embryo und embryotheca bei den laubmoosen. Eine histogenetische und morphologische un- 
tersuchen. E. Schweizerbart'sche Verlagsbuchhandlung, Stuttgart.

Rushing, A. E. \& Z. B. Carothers. 1986. Comparative studies of spermatogenesis in the Bryopsida. III. Blepharoplast morphology in Thuidium delicatulum. THE BRYOLOGIST 89: 144-151.

SANDERSON, M. J. 1996. How many taxa must be sampled to identify the root node of a large clade? Systematic Biology 45: 168-173.

SCHUSTER, R. M. 1984. Comparative anatomy and morphology of the Hepaticae, pp. 760-891. In R. M. Schuster (ed.), New Manual of Bryology, Vol. 2. Hattori Botanical Laboratory, Nichinan, Japan.

1997. On Takakia and the phylogenetic relationships of the Takakiales. Nova Hedwigia 64: 281-310.

SHAw, A. J. 2000. Phylogeny of the Sphagnopsida based on chloroplast and nuclear DNA sequences. THE BRYOLOGIST 103: 277-306.

- \& L. E. ANDERson. 1988. Peristome development in mosses in relation to systematics and evolution. II. Tetraphis pellucida (Tetraphidaceae). American Journal of Botany 75: 1019-1032.

\& B. D. Mishler. 1987. Peristome development in mosses in relation to systematics and evolution. I. Diphyscium foliosum (Buxbaumiaceae). Memoirs of the New York Botanical Garden 45: 55-70.

B. D. Mishler \& L. E. Anderson. 1989a. Peristome development in mosses in relation to systematics and evolution. III. Funaria hygrometrica, Bryum pseudocapillare and B. bicolor. Systematic Botany 14: 24-36. - $\&$ - 1989b. Peristome development in mosses in relation to systematics and evolution. IV. Haplolepidae: Ditrichaceae and Dicranaceae. THE BRYOLOGIST 92: 314-325.

Smith, D. K. \& P. G. DAvidson. 1993. Antheridia and sporophytes in Takakia ceratophylla (Mitten) Grolle: evidence for reclassification among the mosses. Journal of the Hattori Botanical Laboratory 73: 263-271.

SwOFFORD, D. L. 1999. PAUP*. Phylogenetic Analysis Using Parsimony (* and Other Methods). Version 4. Sinauer Associates, Inc., Sunderland, MA.

VITT, D. H. 1984. Classification of the Bryopsida, pp. 676-759. In R. M. Schuster (ed.), New Manual of Bryology, Vol. 2. Hattori Botanical Laboratory, Nichinan, Japan.

B. Goffinet \& T. A. Hedderson. 1998. Ordinal level classification of the mosses: questions and answers for the 1990's, pp. 113-123. In J. W. Bates, N. W. Aston \& J. G. Duckett (eds.), Bryology for the Twenty-first Century. Maney Publishing and British Bryological Society, Leeds, U.K

Wheeler, J. A., D. P. Wall, K. Johannes \& B. D. MishLER. 2000. Congruence and convergence in the moss family Calymperaceae: phylogenetic analysis of two chloroplast genes ( $r b c \mathrm{~L}$ and $r p s 4)$ and morphology. Systematic Biology (in press).

Wigglesworth, G. 1947. Reproduction in Polytrichum commune L. and the significance of the rhizoid system. Transactions of the British Bryological Society 1: 4-13.

Withey, A. 1996. Systematic studies of the Spiridentaceae (Musci). Ph.D. dissertation, Duke University, Durham, $\mathrm{NC}$.

ZANDER, R. H. 1993. Genera of the Pottiaceae: Mosses of harsh environments. Bulletin of the Buffalo Society of Natural Sciences 32. Buffalo, NY.

ms. submitted Dec. 9, 1999; accepted Feb. 7, 2000.

\section{APPENDIX 1}

\section{MORPHOLOGICAL CHARACTERS}

The work of Garbary et al. (1993) provided many of the ultrastructural characters used in this analysis, although only a selection of the many characters discussed and analyzed in that paper are included here. For illustrations and descriptions of spermatogenesis characters, several generally available texts can be consulted (Carothers \& Duckett 1979; Carothers \& Rushing 1988; Duckett \& Carothers 1979; Duckett et al. 1982, 1983). Data on ultrastructural characters and distribution of states within the mosses were obtained from published descriptions (Bernhard \& Renzaglia 1995; Brown \& Carothers 1986; Carothers \& Brown 1985; Carothers et al. 1997; Duckett \& Bell 1977; Duckett \& Renzaglia 1986; Neidhart 1979; Paolillo et al. 1968a,b; Rushing \& Carothers 1986).

1. Antheridial operculum cells. (0: absent; 1: more than 2; 2: variable; 3: single). (Garbary et al. 1993, char. 7).

2. Jacket cell chromoplasts. (0: chromoplasts absent; 1: chromoplasts present). Where chromoplasts are present, antheridial surface cells become yellow-orange at maturity. See Duckett and Carothers (1979, p. 409). (Garbary et al. 1993, char. 9).

3. Nascent spermatids. (0: paired; 1: not paired). After the final mitotic division in the androcyte mother cell, the nascent spermatids may be paired. For a description of this process see Renzaglia and Duckett (1987). (Garbary et al. 1993, char. 12).

4. Diagonal spindle in the final mitotic division. (0: absent; 1: present). For a description see Renzaglia and Duckett (1987). (Garbary et al. 1993, char. 14).

5. Basal body stagger. (0: not staggered; 1: moderately staggered; 2 : strongly staggered; 3 : numerous basal bodies with continuous stagger). (Garbary et al. 1993, char. 19). 6. Lamellar strip position. (0: under all basal bodies; 1 : under anterior basal body only; 2: later under some basal bodies). The lamellar strip underlies either the anterior or both anterior and posterior flagellar basal bodies, or in some cases underlies some of a larger number of flagellar in a later stage of development. See general texts and Renzaglia and Duckett (1991). (Garbary et al. 1993, char. 38). 7. Aperture type. (0: absent; 1: open; 2: closed). The lamellar strip underneath the anterior basal body may be entire or spline tubules may be absent leaving an aperture. Such an aperture may be closed or can extend to the anterior end of the lamellar strip. While the presence or absence of the aperture seems to be constant within major groups of land plants, whether or not the aperture is open shows some variability, and may be informative at less inclusive taxonomic levels. At present there are little data on this variability. (Garbary et al. 1993, char. 30, modified).

8. Stray spline microtubule. (0: absent; 1 : present; 2 : develops late). In mosses a "stray" or divergent microtubule has been shown to occur, forming the left-hand margin of the spline and running towards the posterior basal body. There may be variation in this pattern within mosses, but there are little data available. Garbary et al. (1993) observed developmental differences in the stray microtubule in Sphagnum, which is therefore coded as a separate state from that seen in other mosses. See Carothers and Rushing (1988) for discussion. (Garbary et al. 1993, char. 39).

9. Maturational elongation of the anterior mitochondrion. (0: no elongation; 1: posterior elongation). See Renzaglia and Duckett (1991) for discussion. (Garbary et al. 1993, char. 44)

10. Direction of nuclear compaction. (0: outer shell; 1 : anterior to posterior; 2 : equal rates along nucleus; 3 : gen- 
eral increase in density). See Renzaglia and Duckett (1988, pp. 226-227) for a description of this process. (Garbary et al. 1993, char. 65).

11. Condensation of chromatin strands. (0: spaghetti-like; 1: perpendicular to spline; 2: spiraling round central strand; 3: general compaction; 4: spikes; 5: irregular plates; 6: solid mass from anterior tip). See Renzaglia and Duckett (1988, pp. 226-227) for a description of this process. (Garbary et al. 1993, char. 66).

12. Plastid determination of division polarity. (0: from poles; 1 : asymmetric; 2 : absent). In the in-group and majority of the out-group taxa the spermatids possess a single plastid. During mitotic divisions the position of the daughter plastids determines the polarity of division. (Garbary et al. 1993, char. 81).

13. Starch grains in the single spermatid plastid. (0: more than one; 1: one). (Garbary et al. 1993, char. 83).

14. Sheets of endoplasmic reticulum. (0: absent; 1 : present). See Renzaglia and Duckett (1988, pp. 230-231) for a description. (Garbary et al. 1993, char. 88).

15. Antheridium form. (0: long thin stalk; 1 : short stalk). The "moss-type" antheridium develops from an apical cell and is ovoid with a short broad multiseriate stalk, while in many of the out-group taxa the antheridium develops from a filament of cells, is spheric, and has a long, thin, biseriate stalk (Crandall-Stotler 1984, pp. 11031104; Schuster 1984, pp. 852-858). Character 2 of Garbary et al. (1993) relates to ontogeny of the antheridium and would be preferable; however, this is difficult to observe; published descriptions and illustrations are lacking or unconvincing and consequently the morphology of the mature antheridium is used here. In out-group taxa where the antheridia are known to develop from an immersed rather than a superficial cell (Kenrick \& Crane 1997; Schuster 1984), the character is coded as unknown. Mosstype antheridia in Takakia are described by Smith and Davidson (1993).

16. Mucilage papillae. (0: absent; 1: present). In Andreaeobryum (Fig. 6D-E) and Takakia beaked "mucilage papillae" are present. Axillary hairs and mucilage papillae must be considered as separate characters, since they are distinct in both structure and position, and are both present in the same plants. Descriptions of mucilage papillae in Takakia lepidozioides are taken from Proskauer (1962), in Takakia ceratophylla from Schuster (1997), and in Andreaeobryum from Murray (1988). Mucilage papillae consist of cells with attenuate tips ("beaks") that are open at maturity and exude mucilage (Fig. 6D-E). In Takakia the beaks are more elongate than in Andreaeobryum. Mucilage papillae occur in dense clusters on rhizomatous axes in Takakia and singly or in clusters on protonema, rhizoids, stems, and tips of perichaetial leaves in Andreaeobryum. Frequently more than one mucilage papilla develops from a single epidermal base cell, and they may be sessile or on multicellular, branching stalks.

17. Axillary hairs. (0: distal cell short-ovate; 1 : distal cell elongate). These are normally uniseriate and unbranched, and consist of one or more short, thick-walled basal cells and one or more ovate or cylindric, thin-walled distal cells. The terminal cells lack beaks, and mucilage is thought to be exuded through the intact cell wall (Proskauer 1962). Variation in size, shape, and number of basal and distal cells is considerable (Hedenäs 1989), but in the out-group taxa and some mosses the hairs consist of a single basal cell and a single short-ovate distal cell (Duckett, unpubl. data).

18. Food-conducting cells. (0: absent; 1 : present). Studies of food-conducting cells in bryophytes have shown that these share structural similarities (cytoplasmic polarity and endoplasmic microtubules) with the more elaborate leptoids seen in the Polytrichales. The sieve elements of vascular plants lack these features and are therefore not considered homologous (Ligrone \& Duckett 1994; Ligrone et al. 2000).

19. Water conducting cells. (0: absent; 1 : imperforate; 2 : perforate). The hydroids seen in mosses are elongate and thin, with long slanting end walls, and completely imperforate (Ligrone et al. 2000).

20. Protonema. (0: thalloid; 1: multiseriate; 2: filamentous). The term protonema is used here for the structures formed following germination of the spore, whether thread-like or not. For descriptions of thalloid protonema (Sphagnum) see Goode et al. (1993a); for multiseriate protonema (Andreaea, Andreaeobryum) see Murray (1988) and Figures 5A-G, 6A-E; and for filamentous protonema see Duckett et al. (1998). Data on Takakia for characters 20-29 are missing because rhizoids are not produced in culture nor in the wild, and it has not yet proved possible to grow Takakia from spores.

21. Side branch initials. (0: absent; 1 : present). Branching in the uniseriate filamentous protonema and the rhizoids may be the result of division of the apical cell, or by the formation of side branch initials (SBIs). (Duckett et al. 1998).

22. Cytokinin induced bud formation. (0: not induced; 1 : induced). Exposure of rhizoids or caulonema to cytokinins induces the formation of buds from side branch initials (Fig. 7B; Bopp 1983).

23. Abscisic acid (ABA) induced brood cell formation. (0: absent; 1: present). Ovoid or spheric brood cells occur naturally on chloronemal protonema in old or dried cultures and in the wild. In some taxa, they are thick-walled and may have some function in desiccation tolerance. Application of ABA to young cultures may induce brood cell formation (Goode et al. 1992, 1993b).

24. Protonemal side branch initial plates. (0: filamentous only; 1 : spathulate; 2: funnel; 3: narrow). The SBIs normally develop to produce filamentous protonema, but in several taxa multiseriate structures (called "plates", but of several different forms) develop from the SBIs. ( $D i$ physcium, Duckett 1994; Tetraphis, Goode et al. 1992; Polytrichaceae and Oedipodium, Figs. 6 F-H, 7A-F).

25. Parenchymatous protonemal appendages. (0: absent; 1: present). Massive terete appendages are produced on the protonema in Andreaeobryum (Murray 1988), but are not derived from SBIs (Figs. 5E-F, 6A-B). These have now also been seen in Andreaea (Fig. 5A-D) after successful germination in culture.

26. Bud position. (0: base of SBI; 1: center of "plate"). In taxa in which "plates" develop from SBIs, the gametophore buds normally develop from a position at the base of the SBI. In some taxa buds develop from cells distal to the SBI base, in the center or margins of the "plate." (Fig. 7A-D).

27. Thigmotropism. (0: absent; 1 : present; 2 : well developed). Rhizoids, especially the finer branches, wind tightly around any solid object with which they come into contact. This is especially pronounced in the Polytrichales (Fig. 7E; Duckett et al. 1998; Wigglesworth 1947).

28. Archegonium position. (0: anacrogynous; 1: acrogynous, primary module; 2 : acrogynous, lateral module). The fertile module may be anacrogynous, that is, the apical cell can produce archegonia and also continue vegetative growth, so the archegonia become scattered between the leaves below the apex. If the apical cell ceases growth after producing archegonia, the fertile module is determinate and acrogynous. In Andreaea and Andreaeobryum, the archegonia may terminate the stem, but frequently are 
found between leaves below the apex indicating that the plants are anacrogynous (Murray 1988).

29. Antheridium position. (0: axillary; 1: terminal). In Sphagnum, antheridia are produced on anacrogynous lateral modules (Cavers 1910) while in Takakia they are located in the leaf axils of the main stem (Schuster 1997; Smith \& Davidson 1993).

30. Calyptra. (0: basal collar; 1: before meiosis; 2: after meiosis). This complex character consists of two elements: the timing of sporangium emergence relative to meiosis, and the rupture of the epigonium to form a basal sheath or a terminal calyptra. For descriptions of calyptra formation in Andreaea and Andreaeobryum see Murray (1988); for Takakia see Renzaglia et al. (1997).

31. Sporophyte transfer cells in placenta with labyrinthine walls. (0: absent; 1: present). For discussion and descriptions of characters 33-35 see Ligrone et al. (1993). 32. Gametophyte transfer cells in placenta with labyrinthine walls. (0: absent; 1: adjacent to intercellular spaces; 2: on inner tangential walls; 3 : in several layers of cells). 33. Foot shape. (0: cup shaped; 1: bulbous; 2: short conic; 3: long conic-tapering).

34. Dehiscence of sporangium. (0: valvate-hepatic; 1: valvate, sutured; 2 : valvate, nonsutured; 3 : operculate; 4 : linear; 5: transverse).

35. Peristome. (0: absent; 1: nematodontous; 2: haplolepidous; 3: diplolepidous-opposite; 4: diplolepidous-alternate).

36. Columella. (0: not formed; 1: dome shaped; 2 : cylindric). In the majority of mosses, including Takakia, a central columella is formed from the inner part of the endothecium, and the sporogenous archesporium is derived from the outer layer of the endothecium. The archesporium may overarch the columella, which is then referred to as domed, or may be interrupted by the upper portion of the cylindric columella. In Sphagnum, the spore sac is derived from the inner layer of the ampithecium and the endothecium forms the columella only.

37. Apical growth of sporophyte. (0: none; 1: limited; 2 : extended). Development of the embryonic sporophyte is discussed by Roth (1969) and summarized by CrandallStotler (1984). In Sphagnum, horizontal divisions in the zygote form a filament, the cells of which then divide further to form the sporophyte, whereas in other mosses an apical cell differentiates, resulting in a limited period of apical growth. Extended apical growth results from development of a meristematic region. Detailed description of sporophyte development in Takakia ceratophylla is lacking, but appears to follow a similar pattern of development to that seen in other mosses (Renzaglia et al. 1997).

38. Intercalary growth of sporophyte. (0: absent; 1: brief seta meristem; 2: prolonged intercalary meristem). (Crandall-Stotler 1984; Roth 1969). In hepatics, no meristematic region is formed and seta growth is the result of generalized division and expansion. The embryonic sporophyte of most mosses develops an intercalary meristem that produces the foot and lower seta by basipetal division, and the upper seta and capsule base by acropetal division. No intercalary meristem or seta is formed in Sphagnum or Andreaea. In anthocerotes, meristematic activity is prolonged.

39. Abaxial rhizoid branching. (0: free branching; 1: distal-contact). Rhizoids in mosses are multicellular and frequently highly branched. They originate from several distinct cellular positions (Koponen 1968; Newton \& De Luna 1999). Those that develop from the abaxial leaf bases may branch freely or may only branch when in contact with a substrate.

40. Complex oil bodies. (0: absent; 1: present).

41. Elaters. (0: absent; 1: present). 